\title{
Factors influencing the adoption intention of using mobile financial service during the COVID-19 pandemic: the role of FinTech
}

\author{
Chen Yan ${ }^{1} \cdot$ Abu Bakkar Siddik ${ }^{2}\left(\right.$ Nazma Akter $^{3} \cdot$ Qianli Dong $^{1}$
}

Received: 23 September 2021 / Accepted: 5 November 2021

(c) The Author(s), under exclusive licence to Springer-Verlag GmbH Germany, part of Springer Nature 2021

\begin{abstract}
Access to financial services is regarded as one of the most pressing issues confronting communities worldwide sequel to the COVID-19 pandemic. In this regard, FinTech applications such as mobile financial service (MFS) play an essential role in building resilience during the pandemic. Hence, the aim of the study is to investigate the role of MFS platforms in economic resilience by empirically evaluating the determinants that influence the intention of Bangladeshi users toward adopting MFS platforms during the COVID-19 pandemic, through an extension of the Unified Theory of Acceptance and Use of Technology (UTAUT). Using the core structures of the UTAUT, the theoretical model was constructed based on the consumption attributes of financial services such as perceived value, as well as additional situational factors from the extended valence framework, including risk and trust. To test the model, data was obtained from 227 potential MFS users in Bangladesh with the aid of a structured questionnaire survey. Subsequently, the Structural Equation Modeling (SEM) approach was used to analyze the data. The findings showed that social influence, perceived trust, and perceived value are strongly related to the intention of users to adopt MFS platforms, whereas, perceived risk, performance expectancy, and effort expectancy were observed to influence users' perceived value of the MFS platforms during the COVID-19 pandemic. Interestingly, the study results indicated that the users' perceived risk did not influence their intention to adopt MFS platforms during the pandemic. Therefore, the suggested adoption of the MFS framework during and after the pandemic could contribute to the existing research on the adoption of information technology (IT) through the expansion of the UTAUT, in which the performance and effort expectancy of users influence their intention to indirectly adopt MFS through perceived value. Finally, the significant policy implications and future research directions are further addressed.
\end{abstract}

Keywords FinTech $\cdot$ Mobile financial service $($ MFS) $\cdot$ IT adoption $\cdot$ Perceived value $\cdot$ UTAUT $\cdot$ COVID-19 $\cdot$ Bangladesh

\section{Introduction}

To ease financial-economic activity in modern economies, a wide range of functions are performed by the financial service industry. Access to financial services is regarded

Responsible Editor: Nicholas Apergis

Abu Bakkar Siddik

1s190309@sust.edu.cn

Chen Yan

2016023009@chd.edu.cn

Nazma Akter

nazma.sob@aust.edu

Qianli Dong

dongq1@chd.edu.cn as one of the primary facilitators of socioeconomic resilience during the COVID-19 pandemic (Al Nawayseh 2020; Karusala et al. 2019). The financial sector has been recently transformed due to technological advances in Information and Communication Technologies (ICT), resulting in more effective and creative delivery of services. On the other hand, financial technology (FinTech)

1 School of Economics and Management, Chang'an University, Xi' an 710064, Shaanxi, China

2 School of Economics and Management, Shaanxi University of Science and Technology (SUST), Weiyang District, Xi' an 710021, Shaanxi, China

3 School of Business, Ahsanullah University of Science and Technology, Tejgaon Industrial Area, Dhaka 1208, Bangladesh 
has enabled consumers to access innovative financial services, such as online payment, mobile financial services, savings and investments, budgeting and financial planning, peer-to-peer lending, and crowdfunding (Xie et al. 2021), as the connection of digital technologies and the financial industry deepens (Jiang et al. 2018). Besides, FinTech provides the financial sector and the public in making their daily transactions more affordable, convenient, and secure (Chen et al. 2019; Puschmann 2017). The use of technologies has been accelerated by the COVID19 in virtually all areas of the world (Al Nawayseh 2020; Khatun et al. 2021). Financial experts predict that the epidemic has accelerated the adoption of digital banking systems by 3 to 10 years (Reich 2021). During the pandemic, mobile technology proved critical in maintaining a germ-free environment, and it is still effective and useful in the post-COVID-19 era (Sharifi et al. 2021). In this regard, the COVID-19 outbreak may also have expedited the use of FinTech platforms such as mobile banking services in developing economies like Bangladesh (Khatun et al. 2021). Mobile Financial Services (MFS) are banking services mediated by mobile networks, thus enabling customers to conduct banking and other financial transactions using their mobile phones (Azad 2016; Biswas 2021; Khatun et al. 2021). Therefore, MFS can be described as the products and services offered by a financial institution to its consumers via mobile devices to enhance their access to financial services and lower their expenses.

Even before the COVID-19 pandemic, contactless payments had already achieved a breakthrough (Harrison 2021). However, the adoption of this medium of payment is now witnessing its record high, as its has been observed to prevent the spread of viruses (Zhao \& Bacao 2021). Several governments around the world are exploiting different alternatives to cash transactions, such as online banking, mobile payment, mobile banking, and agent banking (Al Nawayseh 2020). In Bangladesh, MFS is the most popular alternative to cash payments during the pandemic (Khatun et al. 2021; Rahman 2020). Since the implementation of lockdowns, MFS providers have observed a significant increase in the number of requests for digital transactions. Following the countrywide lockdown which began on the $26^{\text {th }}$ of March, 2020 in Bangladesh, the number of registrants for mobile banking services dramatically increased (Murtuza 2020). As of January 2020, there were 80.92 million registered mobile banking customers, which significantly increased to 99.34 million in December (Khatun et al. 2021; Murtuza 2020). The number then gradually increased over the following 15 months, reaching 102.80 million in March 2021, which is a faster rate than the previous year. As a result, it can be stated that during this outbreak, MFS providers play an important role in financial integrations in developing nations, since it has been proven to be an ideal solution for promoting a germ-free atmosphere (Harrison 2021; Zhao and Bacao 2021).

Scientific research has been dominated by works of literature about the COVID-19 pandemic, and unsurprisingly, articles on health sciences have accounted for $88.23 \%$ of COVID-19 publications (Daragmeh et al. 2021; Ruiz-Real et al. 2020). However, research on social sciences and technology has also significantly increased throughout the pandemic (Ruiz-Real et al. 2020). Numerous studies have been conducted to acquire a better understanding of the elements facilitating the adoption of information technologies in banking processes (Shahabi et al. 2021), E-commerce (Prasetyo et al. 2021; Salem and Nor 2020), health (Rahi et al. 2021), education (Rizun and Strzelecki 2020), FinTech (Al Nawayseh 2020; Puriwat and Tripopsakul 2021), mobile payment(Sreelakshmi and Prathap 2020; Zhao \& Bacao 2021), e-wallet (Aji et al. 2020; Daragmeh et al. 2021), online banking (Sudarsono et al. 2020), and others (Al-Maroof et al. 2020; Jonker et al. 2020). Besides, a few studies have tried to identify the factors influencing the adoption of mobile banking in Bangladesh during the COVID-19 pandemic, based on published articles and secondary data (Khatun et al. 2021; Shakila 2021). To the best of our knowledge, there is a scarcity of research on the factors impacting the uptake of mobile financial services during the COVID-19 pandemic in the context of an emerging country, particularly Bangladesh, where the MFS business has experienced an enormous development during the pandemic (Khatun et al. 2021). Therefore, the current study intends to investigate the role of MFS platforms in economic resilience by empirically evaluating the determinants that influence the intention of Bangladeshi users to adopt MFS platforms during the COVID-19 pandemic.

The Unified Theory of Acceptance and Use of Technology (UTAUT) (Venkatesh et al. 2012) has been widely used as the baseline model to comprehend the adoption intention of individuals toward new technologies, such as FinTech (Al Nawayseh 2020; Khatun \& Tamanna 2020; Xie et al. 2021), mobile banking (Baptista and Oliveira 2015), blockchain (Kabir and Islam 2021; Queiroz and Fosso Wamba 2019), and online banking (Sharma et al. 2020). To bridge the aforementioned research gap, this study proposed an MFS adoption framework during the COVID-19 pandemic by combining the consumption attributes of financial services like the perceived value with additional contextual aspects from the extended valence framework such as trust and risk, through the use of the basic constructs of the UTAUT. As a result, the current study provides some useful theoretical and practical implications in the adoption of mobile financial services during the COVID-19 epidemic, particularly in developing countries such as Bangladesh.

The remainder of this study is outlined as follows: the "Research Background, Theoretical Foundation and 
Hypotheses Development" section presents the study background which includes the emergence of MFS in Bangladesh; COVID-19 and MFS in Bangladesh; the role of MFS in Resilience, FinTech, MFS, and Innovation; and the development of theoretical foundations and hypotheses. The "Research Methodology" section discusses the methodology of the research, including sample and data collection, survey instruments, and data processing techniques. The "Results and Findings" section covers the findings of the study, while the "Discussion and Conclusion" section presents the discussion of result and conclusion of the study. The "Theoretical and Practical Implications of the Study" section discusses the study's theoretical and practical consequences, while the "Study Limitations and Future Research" section discusses the study's limitations and future research prospects.

\section{Research background, theoretical foundation, and hypotheses development}

\section{FinTech, MFS, and innovation}

A wide range of functions were performed by the financial service industry in modern economies to ease financialeconomic activity (Al Nawayseh 2020). Financial inclusion was seen as a critical accelerator of socioeconomic resilience throughout the pandemic (Adaba et al. 2019; Karusala et al. 2019). Following the advancement in ICT, financial businesses have transformed over the decades, and this has facilitated a more efficient and inventive service delivery. Developments in digital banking make it possible for vulnerable groups, particularly in developing nations, to access financial resources more efficiently (Amidjaya and Widagdo 2020; Gomber et al. 2018; Khatun et al. 2021; Puschmann 2017; Zheng et al. 2021). FinTech has resulted in the advancement of the finance sector by lowering the costs of transactions, and making them more convenient and secure (Chen 2016; Puschmann 2017). FinTech, often known as financial technology, is a new industry that renders creative financial services that are ICT-driven (Arner et al. 2015). Furthermore, FinTech comprises a wide range of mobile services, including payments, fund transfers, loan requests, insurance, asset management, investments, and crowdfunding (Bharadwaj et al. 2019; Chen 2016; Dhar and Stein 2017; Puschmann 2017). MFS is a means of providing banking services that connect banking with mobile networks and enables customers to conduct banking and other financial transactions using their mobile phones (Azad 2016; Biswas 2021; Khatun et al. 2021). MFS includes products and services offered by financial institutions to consumers via mobile devices to enhance their access to financial services and reduce their expenses. The open innovation concept has been further used to increase the ability of organizations to innovate while simultaneously reducing costs (DesJardine et al. 2019; Karagiannaki et al. 2017). The FinTech ecosystem is a growing association of industry participants comprising established businesses, startups and consumers (Puschmann 2017). This relationship between participants in the financial industry could never have been achieved without the help of open innovation efforts (DesJardine et al. 2019; Karagiannaki et al. 2017; Tabetando and Matsumoto 2020). As a result, this new strategy enables businesses to effectively leverage their business environment stakeholders to increase their adaptability in response to such changes by shortening development cycles and process automation (Tabetando and Matsumoto 2020). In Bangladesh, advantageous rules and policies by the Bangladesh Bank (the central bank of Bangladesh), dependable telecommunications infrastructure and products, as well as numerous mobile banking inclusion programs, all contribute to the widespread usage of FinTech services. Therefore, it can be asserted that open innovation plays a critical role in the development of new financial instruments that boost an organization's capability.

\section{Role of MFS in resilience}

In recent years, the empirical literature on resilience has expanded to include numerous areas such as health, emergency management, etc. (Al Nawayseh 2020; Karusala et al. 2019; Kingiri and Fu 2020). The resilience of individuals is their capacity to adapt to external shocks in their surroundings (Bharadwaj et al. 2019; Karusala et al. 2019; Kingiri and $\mathrm{Fu} 2020$ ). In difficult conditions, individuals might positively adapt to their surroundings by utilizing resources and characteristics, such as problem-solving abilities (Dávid 2017; Kingiri and Fu 2020). In the development of resilient communities and individuals during crises or emergencies, ICT plays a crucial role (Goo and Heo 2020; Heeks and Ospina 2019; Kingiri and Fu 2020). In this regard, digitized financial innovations, especially Fintech, enable disadvantaged people, particularly in developing nations, to obtain greater access to financial resources, thereby strengthening their financial stability during the crises (Arevian et al. 2018; Hussain et al. 2019; Liu et al. 2019; Pal et al. 2020; Senyo and Osabutey 2020). Consumers in underdeveloped nations can access a wider range of financial services through mobile applications, including payments, savings, loans, and microcredit, etc. (Adaba et al. 2019; Bharadwaj et al. 2019; Dávid 2017; Kingiri and Fu 2020). The MFS industry in Bangladesh is expanding at a rapid pace (Rahman 2021), and a new height will be achieved as soon as the compatibility between the operators and compliance is secured, the costs of services are reduced, and a level playing field is guaranteed. The industry has grown into a one-stop shop for all types of transactions, including money transfers and 
payments for utilities, transit, education, medical care, and retail purchases. This development has expedited the integration of finance. Following the pandemic, citizens in Bangladesh are increasingly turning to MFS as a means of money transfer, purchase of goods and services, purchase of airtimes, and bill payments (Dalim 2020). Since the inception of COVID-19, operators of MFS have recorded a significant increase in the number of consumers and volume of transactions (Dalim 2020; Islam 2021). Therefore, a very good phenomenon with the COVID-19 incident is observed for both the MFS account and the transaction, as the number of transactions conducted via MFS significantly increased in comparison to the pre-COVID-19 era, attaining 307.3 million in March 2021 (Younus et al. 2021). Therefore, it can be observed that MFS providers played a significant role in financial integration during the outbreak, as their operations assisted the government in taking immediate action on the pandemic.

\section{The Emergence of MFS in Bangladesh}

In Bangladesh, mobile banking is terminologically referred to as mobile financial services (MFS) (Azad 2016), and its adoption in the country dated back to the $31^{\text {st }}$ of March, 2011 (Azad 2016; Khatun et al. 2021). In general, numerous private commercial banks (PCBs) are observed to have expanded their mobile banking operations across the country at a rapid rate. In contrast, a few state-owned commercial banks have only recently begun to go in this direction. Simultaneously, specialist development banks and foreign commercial banks are yet to launch mobile banking services. In May 2011, Dutch Bangla Bank Limited launched the first mobile banking service named "Rocket" in Bangladesh, but full operations only began after 2 years (Khatun et al. 2021). Twenty-eight banks have been recently granted permission to provide MFS, with many more still in the process of obtaining authorization. Of 28 licensed institutions, only 15 really offer the highlighted services as shown in Table 1.

In the country, these institutions currently provide the following mobile banking services: cash in/out using mobile accounts, individual to business payments (e.g., utility bills payment),disbursement of inward foreign remittances, business to individual payments (such as salary disbursement by organizations and industries), government to person payments and vice versa (e.g., elderly allowances, freedom fighter allowances, subsidies, tax, levy payments, etc.), and other payments such as DPS, microfinance, insurance premium, and overdrawn facility (Khatun et al. 2021; Sultana and Khan 2017). Bangladesh has made tremendous progress in financial inclusion through the establishment of alternative delivery channels such as mobile banking to render low-cost financial services to the poor and needy. In $2020,48 \%$ of adults were covered by the formal financial services sector, which was previously limited to $20 \%$ in 2013 during the existence of limited MFS (Khatun et al. 2021). The number of mobile banking users in Bangladesh has steadily increased over time, as shown in Figure 1. Therefore, to attract new customers and increase public financial access, it is critical to ensure the security and privacy of all mobile banking transactions.
Table 1 Name of the MFS providers in Bangladesh as of March 2021

\begin{tabular}{lll}
\hline SL & Institutions & Service name \\
\hline 1 & Dutch Bangla Bank Ltd. (DBBL) & Rocket \\
2 & Brac Bank Ltd. (BBL) & B Kash \\
3 & United Commercial Bank Ltd. (UCBL) & U Cash \\
4 & Mercantile Bank Ltd. (MBL) & My Cash \\
5 & One Bank Ltd.(OBL) & OK wallet \\
6 & Bangladesh Post Office (BPO) & Nagad \\
7 & Trust Bank Ltd. (TBL) & T-cash \\
8 & Islami Bank Bangladesh Ltd. (IBBL) & M-cash \\
9 & Rupali Bank Ltd. (RBL) & RBL Sure Cash \\
10 & Bangladesh Commerce Bank Ltd. (BCBL) & Sure Cash \\
11 & First Security Islami Bank Ltd. (FSIB) & First Pay Sure Cash \\
12 & National Credit \& Commerce Bank Ltd. (NCCBL) & NCCB Sure Cash \\
13 & South East Bank Ltd. (SEBL) & TeleCash \\
14 & Bank Asia Ltd. (BAL) & Hello \\
15 & IFIC Bank Ltd. (IFICBL) & IFIC Mobile Banking \\
\hline
\end{tabular}

Bangladesh Bank, (2021). For more details, see https://www.bb.org.bd/fnansys/paymentsys/mfsdata.php; accessed on 05-08-2021 


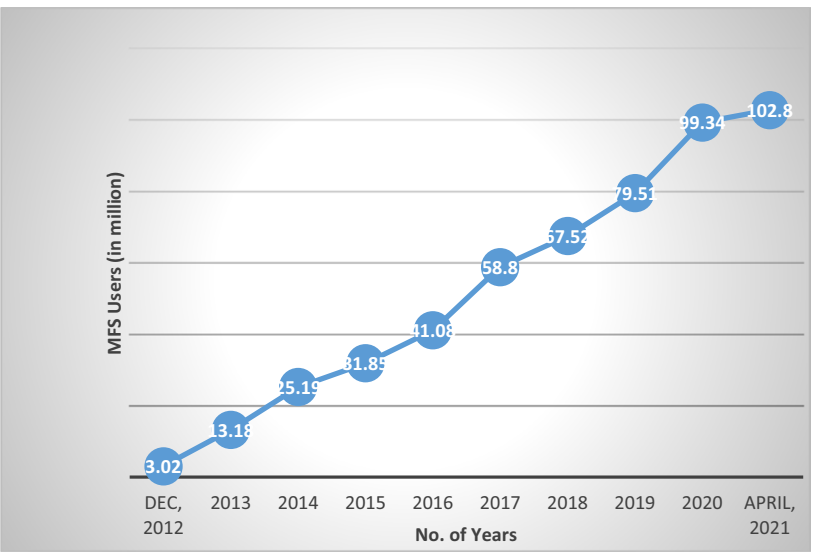

Fig. 1 Trend of MFS users in Bangladesh from December 2012 to April 2021

\section{MFS in Bangladesh during the COVID-19 Pandemic}

Due to the widespread outbreak of the COVID-19 pandemic, the world is experiencing a never before seen humanitarian crisis. This epidemic has significantly altered the lifestyle of people, including their working attitude, shopping habits, payment methods, and bank transactions, among others (Khatun et al. 2021). Banks are now re-assessing their banking products and services during and after the COVID-19 epidemic; in this regard, mobile banking is regarded as a reasonable option, as it provides consumers with easy and safe financial access. Due to the worldwide reaction to the pandemic, contactless payments have become increasingly common, prompting several governments around the world to experiment with different alternatives to cash transactions. As a result, mobile banking has become the most popular alternative to cash payments in Bangladesh (Khatun et al. 2021; Z. Rahman 2020). Since the implementation of lockdowns, providers of MFS have recorded a significant increase in the number of requests for digital transactions. Following the country lockdown that began on the 26th of March, 2020 in Bangladesh, the number of mobile banking users have dramatically increased (Murtuza 2020). As of January 2020, there were 80.92 million registered mobile banking customers, which significantly increased to 99.34 million in December of the same year (Khatun et al. 2021; Murtuza 2020). From January 2020, the number gradually increased over the subsequent 15 months (at a faster rate than the previous year), hitting 102.80 million in March 2021. On the other hand, MFS operators registered 0.3 million additional accounts in April 2020 to support the distribution of funding in export-oriented companies under the government's BDT 5000 crore stimulus package (approximately USD 589 million) (Holy 2020). Another significant factor contributing to the growth of mobile banking users is that the majority of readymade garment (RMG) owners

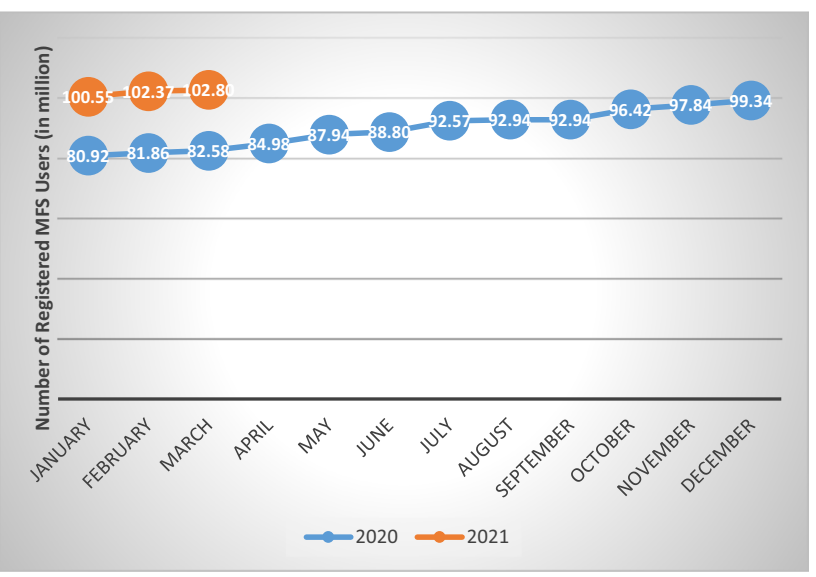

Fig. 2 The trend of registered mobile banking customers during the pandemic

mandated their employees to open mobile banking accounts to receive their salaries and other benefits, which is an excellent initiative to connect low-income earners to a digital financial access platform in Bangladesh. This also reduced the spread of COVID-19 in the country. Although the MFS industry has grown significantly during the epidemic, the cash liquidity situation at the agent points has been exacerbated by the implementation of social distancing in the country (Dalim 2020). Therefore, it can be stated that MFS grew more popular in Bangladesh during the pandemic, as individuals became fearful of the viral transmission and wanted to fulfill supplementary payments such as power, gas, and other utility bills using digital payment methods. Figure 2 depicts the trend of registered mobile banking customers during the pandemic.

\section{Theoretical background and hypotheses development}

To date, various studies have been conducted in sociology, psychology, and information system research to determine the factors that influence an individual's ICT adoption behavior (Xie et al. 2021). During the last three decades, several theoretical strategies have been employed in the study of technology adoption. The most common theories are the Theory of Reasoned Action (TRA) (Fishbein and Ajzen 1977); Theory of Planned Behavior (TPB) (Ajzen 1991); Innovation Diffusion Theory (IDT) (Rogers et al. 2003); Technology Acceptance Model (TAM) (Davis 1985; Davis et al. 1989); Unified Theory of Acceptance and Use of Technology (UTAUT) (Venkatesh et al. 2012) ; the DeLone and McLean model of information success (DeLone and McLean 2003); and Bailey and Pearson's analysis of computer user satisfaction (Bailey and Pearson 1983). Each of these theoretical models contributes to the understanding 
of IT acceptance. However, each paradigm overlooks the contributions of the others.

The adoption of FinTech technologies is mostly determined by contextual factors like social influence, risk, and trust (Al Nawayseh 2020; Ryu 2018; Senyo and Osabutey 2020; Stewart and Jürjens 2018; Xie et al. 2021). However, the majority of past studies on the adoption of FinTech has concentrated on technological variables and ignored the social determinants (Hu et al. 2019; Senyo and Osabutey 2020; Shaikh et al. 2020; Xin et al. 2015). For instance, the TAM was extensively used in the research on the adoption of mobile services (Arias-Oliva et al. 2019; Duane et al. 2014; Z. Hu et al. 2019; Patil et al. 2018; Senyo and Osabutey 2020; Slade et al. 2015), while the use of behavioral theories such as the UTAUT and the extended valence framework remains limited (Abdullah et al. 2018; Al Nawayseh 2020; Senyo and Osabutey 2020). The original UTAUT model posited four major dimensions as determinants of usage intention and behavior: performance expectancy, effort expectancy, social influence, and facilitating conditions (Venkatesh et al. 2012). The extended valence framework, on the other hand, revealed that the intention of customers to utilize technology is influenced by their perception of advantages, risks, and trust (Kim et al. 2008). In this regard, the UTAUT model in combination with the extended valence framework is deemed to be more ideal for fintech services such as mobile banking adoption to provide more insights into other contextual elements, such as risk and trust (Al Nawayseh 2020; Kim et al. 2008; Pal et al. 2019). Customer's adoption of mobile financial services can be viewed as a form of technology adoption to a certain extent. Therefore, this study seeks to present a MFS adoption framework by merging financial service consumption attributes like perceived value with additional contextual aspects from the extended valence framework such as trust and risk using the basic constructs of the UTAUT. The relationships in our study model are illustrated in the subsequent sections, as can be shown in Fig. 3.

\section{Performance expectancy (PE)}

PE can be defined as the degree to which individuals believe that the implementation of new technology would improve their working performance (Venkatesh et al. 2003, 2012). In this study, we regarded PE as the degree to which MFS customers believe that the adoption of mobile banking will increase their performance and productivity. As previously stated, the "received" aspect of perceived value represents the value that users can derive from the MFS platform. The PE indicates the adoption of individuals based on their desire for external incentives (Venkatesh et al. 2003), the "received" component of perceived value (Xie et al. 2021). Previous studies indicated that the concept of PE such as usefulness has a positive impact on perceived value (Kim et al. 2007; Xie et al. 2021). Therefore, it may be asserted that PE has a similar effect on perceived value, as it helps users to improve their performance via the use of mobile banking. Thus, the following research hypothesis is proposed:

Hypothesis $1\left(H_{1}\right)$ : PE positively influences the users' perceived value of MFS platforms during the COVID-19 pandemic.

\section{Effort expectancy (EE)}

EE indicates the ease of using technologies (Salloum et al. 2018; Venkatesh and Davis 2000; Viswanath Venkatesh et al. 2003). According to the UTAUT application, customers are more inclined toward the use of technology if it helps them in the achievement of their goals (Salloum et al. 2018). Thus, EE in this study refers to the perceived usefulness of individuals and ease of use of mobile banking systems. EE is concerned with an individual's effort in the utilization of certain technologies that are associated with
Fig. 3 Conceptual framework of the study

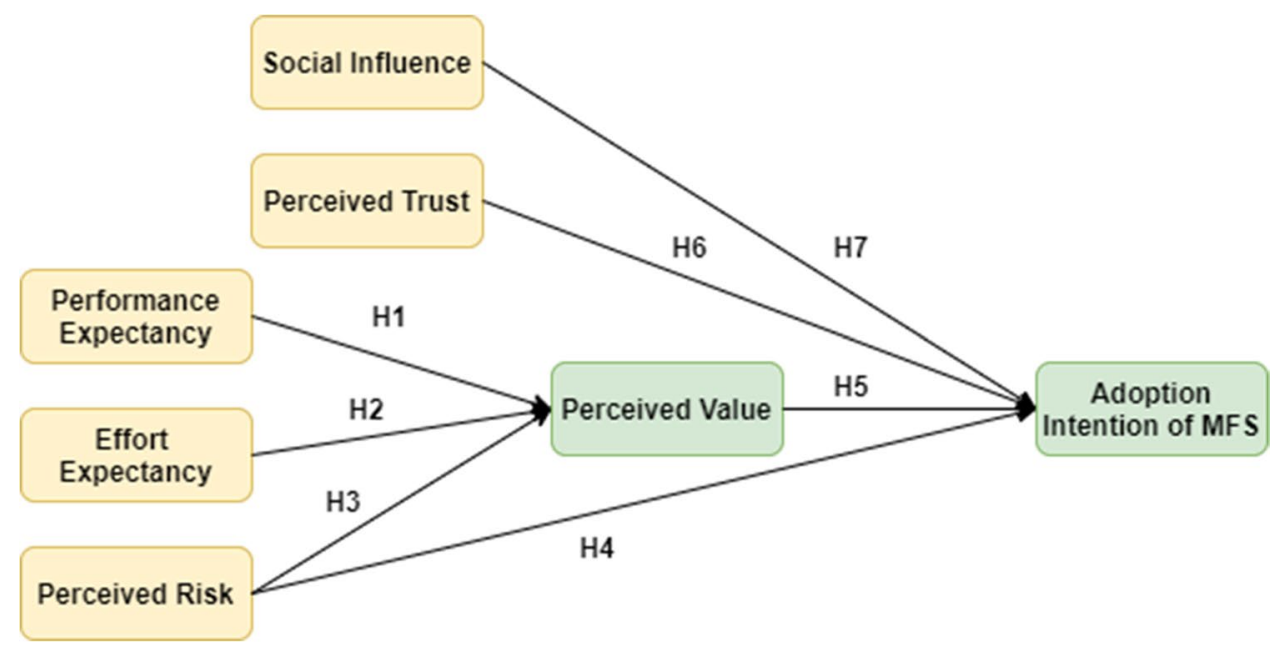


the "given" aspect of perceived values (Xie et al. 2021). The "given" aspect relates to the expenses incurred by users in the use of a FinTech platform (Xie et al. 2021). As the majority of people access the FinTech platform via their mobile phones, the size of their mobile screens, operational restrictions, and the usability of user experiences all limit the EE. According to Xie et al. (2021), EE has a significant effect on the perceived value of FinTech platforms (Xie et al. 2021). Therefore, the EE of MFS platforms is especially essential in this context, as it includes all kinds of non-monetary expenditures. Thus, the following research hypothesis is proposed:

Hypothesis 2 ( $\left.\boldsymbol{H}_{2}\right)$ : EE positively influences users' perceived value of the MFS platforms during the COVID-19 pandemic.

\section{Perceived risk (PR)}

Innovations in the financial services industry always entail a high degree of risks (Kesharwani and Singh Bisht 2012; Kim et al. 2008; Rouibah et al. 2016; Ryu 2018). The PR of FinTech use is regarded as an essential barrier for adopters of technology (Ryu 2018). In FinTech, PR is described as users' perceptions of uncertainty, and the potential negative repercussions associated with the adoption of FinTech (Ryu 2018). According to Peter and Ryan (1976), PR is considered a sign of loss associated with a purchase, which serves as a restriction to buying activity. Featherman and Pavlou (2003) highlighted that a PR represents a potential loss on occasions that an individual uses an e-service to achieve their desired goals (Pavlou 2003). On the other hand, Kim et al. (2008) integrated insecurity with a potential loss and defined PR as a notion that online trading could have negative impacts (Kim et al. 2008). Therefore, the PR is defined in this study as an individual's perception of the possibility of unknown, undesirable outcomes while adopting a mobile financial services platform. The perceived risks connected with FinTech services can be divided into four categories: operational, financial, security, and privacy (Rouibah et al. 2016; Ryu 2018; Slade et al. 2015). These risks make clients more hesitant to adopt new technology like mobile banking, thus lowering their intention to use these applications. Furthermore, the perceived risks of cyber-attacks and currency loss also prevent people from using these services due to the intangibility of FinTech services (Gomber et al. 2018; Stewart and Jürjens 2018). In earlier studies, perceived risks are negatively associated with the intention to use FinTech services (Al Nawayseh 2020; Ryu 2018; Stewart and Jürjens 2018; Xie et al. 2021) and mobile payment acceptance (Slade et al. 2015; Thakur and Srivastava 2014). Therefore, it can be stated that the uncertainty and financial risk associated with e-commerce are primary issues that impede the perceived value and intention of consumers to embrace an MFS platform. Thus, the following research hypotheses are advanced:

Hypothesis $3\left(\mathrm{H}_{3}\right):$ PR negatively influences users' perceived value of the MFS platform during the COVID-19 pandemic.

Hypothesis $4\left(\mathrm{H}_{4}\right):$ : PR negatively influences users' intention to adopt an MFS platform during the COVID19 pandemic.

\section{Perceived value (PV)}

Based on behavioral decision theories, consumers' decision-making behavior is contingent upon their recognition of the exchange between the value of decision outcomes and the efforts required to make a decision (Beach and Mitchell 1978; Payne 1982). The PV is frequently defined as individuals' overall assessment of the utility of goods or services, which is reliant on their perceptions of the "given" and "received" components (Zeithaml 1988). It implies that different people have varying perceived values for the same items or services, and as a result, the perceived value of Fintech services varies among consumers (Xie et al. 2021). According to the behavioral decision theory, the decision behavior of individuals is primarily determined by the trade-off between the utility of the decision (i.e., performance expectancy) and the effort required to make the decision (i.e., effort expectancy), which is equivalent to PV (Johnson and Payne 1985; Xie et al. 2021). The PV indicates the evaluation of the selection technique, which has an impact on the decision-making behavior of individuals (Kim et al. 2007). A few decades ago, scholars, researchers, and academics began to pay attention to $\mathrm{PV}$ and its implications on consumer behavior (Xie et al. 2021). Various studies demonstrated that the PV has a favorable impact on the attitude and behavior of consumers (Chiu et al. 2014; Gordon et al. 2018; Kim et al. 2007; Roy 2016; Xie et al. 2021). A study conducted by Xie et al. (2021) indicated that the PV of consumers positively influenced their intention to adopt FinTech services (Xie et al. 2021). Another study by Shaw and Sergueeva (2019) discovered that the PV influences consumer's intention in the context of mobile commerce (Shaw and Sergueeva 2019). Therefore, peoples's acceptance of mobile financial services might be described as financial serviceconsuming behavior. As previous research had shown that people's perceived value influences their purchasing intentions, their adoption intention will, therefore, be affected by the PV of the MFS. Thus, the following hypothesis is proposed: 
Hypothesis $\mathbf{5}\left(\boldsymbol{H}_{5}\right)$ : There is a significantly positive relationship between the PV and the intention of users to adopt MFS platforms during the COVID-19 pandemic.

\section{Perceived trust (PT)}

Trust has been a primary focus of adoption research, and it is widely used in conjunction with perceived usefulness and perceived ease of use as another critical factor in attracting consumers (Hu et al. 2019). The function of trust is especially significant in FinTech, owing to the substantial data involved in providing services. Therefore, trust is regarded as being essential for technological adoption, particularly for financial transaction systems (Cao et al. 2018; LiébanaCabanillas et al. 2018). Customers' trust is highly valued in the financial services industry, which is extremely competitive and requires the development of strong connections with them (Slade et al. 2015). Trust is a term that relates to users' overall perception of an object's value and can be used to induce behaviors, as it is produced by their inherent characteristics (Hu et al. 2019; Kesharwani and Singh Bisht 2012). Therefore, trust in FinTech applications refers to user beliefs in the capability of applications, transparency, and beneficence (Liao et al. 2011; Stewart and Jürjens 2018). Furthermore, several studies have proven that user trust plays a vital part in the adoption of Fintech services (Al Nawayseh 2020; Xie et al. 2021). In other words, the more trust the user has in a service provider, the more eager the user would be to utilize the service, making behavior promotion easier (Basak et al. 2016; Koksal 2016). Therefore, it can be concluded that the PR of customers is an important factor in the adoption of mobile financial services in Bangladesh. Thus, we formulate the following research hypothesis:

Hypothesis $6\left(\boldsymbol{H}_{6}\right)$ : $P T$ positively influences the intention of users to adopt MFS platforms during the COVID-19 pandemic.

\section{Social influence (SI)}

Customers are mostly influenced by the opinions of other people around them when they use new technology, particularly in the social media era (Ameen et al. 2020; de Sena Abrahão et al. 2016; Grover and Kar 2020). Positive recommendations regarding new technology from family, friends, and coworkers may persuade customers to adopt them (Beldad \& Hegner 2018). Therefore, SI is defined in this study as an individual's critical view of others (e.g., friends, family, relatives and colleagues) who believe that the individual should be using MFS platforms. Social influence, alternatively referred to as subjective norms or images, is described as the degree to which an individual believes that influential individuals believe he or she should adopt a new system (Venkatesh et al. 2012). Additionally, various studies suggested that inclination of individuals toward Fintech services such as mobile payment and online banking is positively influenced by social influence (Al Nawayseh 2020; Alalwan et al. 2018; Chiu et al. 2012; de Luna et al. 2019; de Sena Abrahão et al. 2016; Xie et al. 2021; Yang et al. 2012). According to the aforementioned studies, it is reasonable to assume that the intention of consumers to utilize mobile financial service platforms would be influenced by important groups. Therefore, the following hypothesis is proposed:

Hypothesis $7\left(\boldsymbol{H}_{7}\right)$ : SI positively influences the intention of users to adopt MFS platforms during the COVID-19 pandemic.

\section{Research methodology}

\section{Sample and data collection}

The main aim of the study is to identify the factors influencing the mobile banking users' adoption intention of MFS during the COVID-19 pandemic in Bangladesh. During the pandemic, the MFS industry in Bangladesh experienced enormous growth in the number of registered mobile banking users. In January 2020, there were 80.92 million registered mobile banking customers, which significantly increased to 99.34 million in December of the year (Khatun et al. 2021; Murtuza 2020). The amount gradually increased over the next 15 months (from January 2020) at a faster rate than the previous year, reaching 102.80 million in March 2021. Consequently, the high mobile banking adoption rate of Bangladesh during the outbreak is advantageous to this study. An online-based structured questionnaire was used to obtain primary data and the respondents in this study were the users of MFS platforms in Bangladesh. To evaluate the validity and reliability of the survey items, a pilot test was conducted among 20 Bangladeshi academics working in the information systems and business sectors prior to the main survey. Due to the country's lockdown restrictions, the survey was conducted in Bangladesh between March and April, 2021 through several social media platforms (Google, Facebook, IMO, and WhatsApp). A total of 260 responses were obtained, 33 of which were excluded from the final analysis due to their invalid and missing values. Hence, the final sample of the study was 227 . The demographic information of the respondents is presented in Table 2.

\section{Survey instrument}

An online survey was constructed to fulfill the objective of this study, which was based on an extensive evaluation of the 
Table 2 Respondents' demographic information

\begin{tabular}{|c|c|c|c|}
\hline Variables & Category & Frequency & Percentage \\
\hline \multirow[t]{2}{*}{ Gender } & Male & 161 & 70.9 \\
\hline & Female & 66 & 29.1 \\
\hline \multirow[t]{4}{*}{ Age } & $18-25$ years & 160 & 70.5 \\
\hline & $26-35$ years & 55 & 24.2 \\
\hline & $36-45$ years & 8 & 3.5 \\
\hline & Above 45 years & 4 & 1.8 \\
\hline \multirow[t]{4}{*}{ Educational qualification } & HSC or below & 22 & 9.7 \\
\hline & Undergraduate/diploma & 133 & 58.6 \\
\hline & Master & 53 & 23.3 \\
\hline & M.Phil. or PhD. & 19 & 8.4 \\
\hline \multirow[t]{2}{*}{ Living status } & Urban & 182 & 80.2 \\
\hline & Rural & 45 & 19.8 \\
\hline \multirow{2}{*}{$\begin{array}{l}\text { How familiar are you with the } \\
\text { mobile banking services? }\end{array}$} & Familiar & 214 & 94.27 \\
\hline & Not-familiar & 13 & 05.73 \\
\hline \multirow{4}{*}{$\begin{array}{l}\text { How often do you use mobile } \\
\text { financial services? }\end{array}$} & Never & 4 & 1.8 \\
\hline & Occasionally & 46 & 20.3 \\
\hline & Usually & 50 & 22.0 \\
\hline & Frequently in everyday & 127 & 55.9 \\
\hline
\end{tabular}

Authors' compilation from the field survey, 2021 literature. The survey was divided into two sections: demographic information and measurement items, which were graded on a 5-point Likert scales ranging from strongly disagree $=1$ to strongly agree $=5$. The scales for PE, EE, SI, and adoption intention were adapted from the UTAUT (Al Nawayseh 2020; Venkatesh et al. 2003, 2012; Xie et al. 2021). The measurement scale of perceived value scale was adapted from the previous studies (Kim et al. 2007; Sirdeshmukh et al. 2002; Xie et al. 2021). The user trust scale was derived from the studies of Al Nawayseh (2020); Hu et al. (2019); and Shaw and Sergueeva (2019). The perceived risk measurement scale was also developed based on the past studies (Al Nawayseh 2020; Kim et al. 2008; Pavlou 2003; Xie et al. 2021). Therefore, all measurement items in this research were adjusted to fit the purpose of this research, as demonstrated in Table 3.

\section{Data analysis techniques}

The use of multivariate statistical analysis is strongly recommended, since it produces results that are both reliable and useful. Structural Equation Modeling (SEM) is a type of multivariate analysis that evaluates the relationship between structures. Two SEM methodologies are often used in social science research: Partial Least Squares (PLS) and Covariance-Based (CBSEM) (Gefen et al. 2011). The suggested model and associated measurements were developed using a well-established theory. In this study, the CBSEM was utilized, since it can estimate several dependent variables and account for measurement errors simultaneously. To provide a broad statistical analysis, the primary acquired data in the surveys were analyzed using SPSS 25.0 and AMOS 23.0. Therefore, the reliability and validity of the constructs were analyzed to measure the model, and the structural model further defined the path coefficient and their significance. Overall, the flowchart of research methodology and analytical process, as can be stated in Fig. 4.

\section{Results and findings}

\section{Reliability analysis}

To examine the internal consistency and reliability of the adoption intention model, Cronbach's Alpha (CA) coefficients values and Composite Reliability (CR) were used. According to Hair et al. (2010), the CA values exceeding 0.7 were recognized as acceptable. The findings indicate that the CA values ranged from 0.720 to 0.860 , as shown in Table 4. On the other hand, the CR values ranged between 0.747 and 0.894 , which exceeds the standard limit of 0.7 (Hair et al. 2010) (see Table 5 ). Therefore, based on the findings of the CA and CR, we can conclude that the factors and their associated measurement constructs exhibit sufficient and satisfactory validity and internal reliability (Fornell and Larcker 1981). 
Table 3 Questionnaire items

\begin{tabular}{|c|c|c|c|}
\hline Variables & Items & Descriptions & References \\
\hline \multirow[t]{3}{*}{ Perceived value $(\mathrm{PV})$} & PV1 & $\begin{array}{l}\text { In comparison to the effort required, I find that } \\
\text { using the MFS platform benefits me. }\end{array}$ & \multirow[t]{3}{*}{$\begin{array}{l}\text { (Kim et al. 2007; Sirdeshmukh et al. 2002; Xie et al. } \\
\text { 2021) }\end{array}$} \\
\hline & PV2 & $\begin{array}{l}\text { In comparison to the time I need to invest, I } \\
\text { believe that using the MFS platform is worth- } \\
\text { while. }\end{array}$ & \\
\hline & PV3 & $\begin{array}{l}\text { Overall, the MFS platform provides me with good } \\
\text { value. }\end{array}$ & \\
\hline \multirow[t]{3}{*}{ Performance expectancy (PE) } & PE1 & I utilize the MFS platform daily. & \multirow[t]{3}{*}{ (Venkatesh et al. 2003, 2012; Xie et al. 2021) } \\
\hline & PE2 & $\begin{array}{l}\text { My idle funds are better utilized when I am using } \\
\text { the MFS platform. }\end{array}$ & \\
\hline & PE3 & $\begin{array}{l}\text { Utilizing the MFS platform improves the efficiency } \\
\text { of my financial management. }\end{array}$ & \\
\hline \multirow[t]{3}{*}{ Effort expectancy (EE) } & EE1 & $\begin{array}{l}\text { It would be simple for me to develop competency } \\
\text { with the MFS platform. }\end{array}$ & \multirow[t]{3}{*}{ (Venkatesh et al. 2003, 2012; Xie et al. 2021) } \\
\hline & EE2 & I would find the MFS platform easy to use. & \\
\hline & EE3 & $\begin{array}{l}\text { For me, learning how to utilize the MFS platform } \\
\text { is simple. }\end{array}$ & \\
\hline \multirow[t]{2}{*}{ Social influence (SI) } & SI1 & $\begin{array}{l}\text { People who matter to me believe that I should use } \\
\text { the MFS platform. }\end{array}$ & \multirow[t]{2}{*}{$\begin{array}{l}\text { (Al Nawayseh 2020; Venkatesh et al. 2003, 2012; } \\
\text { Xie et al. 2021) }\end{array}$} \\
\hline & SI2 & $\begin{array}{l}\text { People who have an impact on my behavior believe } \\
\text { that I should use the MFS platform. }\end{array}$ & \\
\hline \multirow[t]{4}{*}{ Perceived risk (PR) } & PR1 & $\begin{array}{l}\text { Using the MFS platform comes with a significant } \\
\text { amount of risk. }\end{array}$ & \multirow[t]{4}{*}{$\begin{array}{l}\text { (Al Nawayseh 2020; Kim et al. 2008; Pavlou 2003; } \\
\text { Xie et al. 2021) }\end{array}$} \\
\hline & PR2 & $\begin{array}{l}\text { When using the MFS platform, there is a signifi- } \\
\text { cant level of unpredictability. }\end{array}$ & \\
\hline & PR3 & $\begin{array}{l}\text { The MFS platform poses a significant level of } \\
\text { security risk. }\end{array}$ & \\
\hline & PR4 & $\begin{array}{l}\text { Overall, I believe that adopting the MFS platform } \\
\text { has minimal advantage over traditional financial } \\
\text { services. }\end{array}$ & \\
\hline \multirow[t]{3}{*}{ User trust (UT) } & UT1 & I trust the MFS platform. & \multirow{3}{*}{$\begin{array}{l}\text { (Al Nawayseh 2020; Hu et al. 2019; Shaw and } \\
\text { Sergueeva 2019) }\end{array}$} \\
\hline & UT2 & I trust the reliability of MFS platform. & \\
\hline & UT3 & I believe that MFS platforms are trustworthy. & \\
\hline \multirow[t]{3}{*}{ Adoption intention (AI) } & AI1 & I intend to adopt MFS in the future. & \multirow{3}{*}{$\begin{array}{l}\text { (Al Nawayseh 2020; Venkatesh et al. 2003, 2012; } \\
\text { Xie et al. 2021) }\end{array}$} \\
\hline & AI2 & $\begin{array}{l}\text { I expect to use the MFS platform regularly in the } \\
\text { future. }\end{array}$ & \\
\hline & $\mathrm{AI} 3$ & $\begin{array}{l}\text { I will strongly advise others to use the MFS } \\
\text { platform. }\end{array}$ & \\
\hline
\end{tabular}

Items that were excluded from the final analysis are not included here

Fig. 4 Flowchart of research methodology

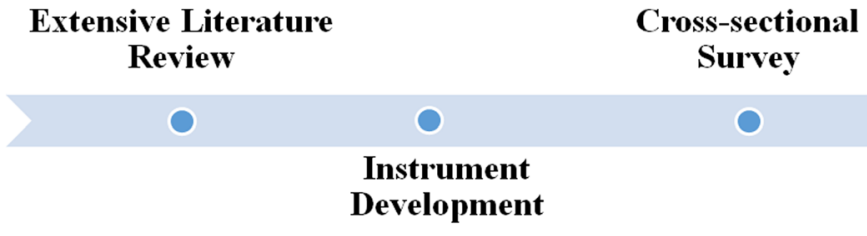

Cross-sectional Survey

\section{Instrument
Development}

Data

Analysis

\section{Discriminant validity}

To assess the discriminant validity, the difference between the square root value of the Average Variance Extracted (AVE) and the correlation coefficient between the constructs were used (Fornell and Larcker 1981). According to Fornell and Larcker (1981), the AVE values for the constructs should be greater than 0.5 if the factor loadings for convergent validity exceed 0.5 (Fornell and Larcker 1981). As observed in Tables 4 and 5, all factor loadings surpassed 
Table 4 Model estimates and reliability

\begin{tabular}{llllll}
\hline Variable & Items & Estimate & C.R. & $p$-value & CA $(\alpha)$ \\
\hline Perceived value (PV) & PV3 & 0.744 & 8.390 & $* * *$ & 0.757 \\
& PV2 & 0.785 & 8.775 & $* * *$ & \\
& PV1 & 0.84 & $*$ & & \\
Performance expectancy & PE3 & 0.716 & $*$ & & 0.819 \\
(PE) & PE2 & 0.634 & 5.825 & $* * *$ & \\
& PE1 & 0.835 & 6.456 & $* * *$ & \\
Effort expectancy (EE) & EE3 & 0.731 & 4.446 & $* * *$ & 0.720 \\
& EE2 & 0.708 & $*$ & & \\
Perceived trust (PT) & EE1 & 0.684 & 4.515 & $* * *$ & \\
& PT3 & 0.838 & 12.013 & $* * *$ & 0.826 \\
& PT2 & 0.874 & $*$ & & \\
& PT1 & 0.763 & 10.493 & $* * *$ & \\
Perceived risk (PR) & PR4 & 0.654 & $*$ & & 0.860 \\
& PR3 & 0.958 & 6.625 & $* * *$ & \\
& PR2 & 0.785 & 6.430 & $* * *$ & \\
& PR1 & 0.877 & 6.647 & $* * *$ & \\
& SI2 & 0.938 & $*$ & & 0.797 \\
& SI1 & 0.581 & 3.073 & .002 & \\
Social influence (SI) & AI3 & 0.772 & 6.185 & $* * *$ & 0.851 \\
Adoption intention (AI) & AI2 & 0.671 & $*$ & & \\
& AI1 & 0.858 & 6.396 & $* * *$ & \\
\hline
\end{tabular}

$C R$, critical ratio; $C A$, Cronbach's alpha; *Unstandardized regression weights anticipated as $1 ; * * *$ Significant level at $\mathrm{p}<0.05$
0.581 and AVE values for all variables ranged from 0.501 to 0.683, indicating their reliability (Fornell and Larcker 1981; Hair et al. 2010). Besides, the values of the AVE square root ranged from 0.708 to 0.826 , which exceeds their inter-factor correlation, as indicated in Table 5. Therefore, no discriminant validity issues were found among the study variables (Fornell and Larcker 1981).

\section{Measurement model of the study}

To assess the construct validity, CR, and model fit, the measurement model was calculated using the first-order Confirmatory Factor Analysis (CFA). Additionally, the study employed the, in which various statistics such as the chisquared statistic, SRMR, RMSEA, GFI, and IFI were used to determine the goodness-of-fit indices ( $\mathrm{Hu}$ and Bentler 1999a). As a result, Table 6 displays the model fit indices for the measurement and structural models. The measurement model produced convergent and reasonably fitted results ( $2 /$ $\mathrm{df}=1.590, \mathrm{p}=0.000, \mathrm{SRMR}=0.032, \mathrm{RMSEA}=0.051$, GFI $=0.903$, and IFI $=0.916$ ), indicating that the goodness-of-fit indices were within acceptable limits (Bentler and Bonett 1980; Hu and Bentler 1999b; Salisbury et al. 2002). On the other hand, the critical ratios (CR) values varied from 3.073 to 12.013 for all measurement items, indicating that the path is significant at $\mathrm{p}<0.01$, as presented in Table 4 . Based on the outputs, it can be concluded that the overall measurement approach for the intention of users to adopt MFS platforms during the COVID-19 epidemic is valid and appropriate.
Table 5 AVE, CR, and correlations

\begin{tabular}{lrrlrlllll}
\hline Variables & \multicolumn{1}{l}{ PV } & PE & EE & AI & PT & PR & SI & AVE & CR \\
\hline PV & $\mathbf{0 . 7 9 1}$ & & & & & & & 0.625 & 0.833 \\
PE & 0.168 & $\mathbf{0 . 7 3 3}$ & & & & & & 0.537 & 0.775 \\
EE & 0.106 & 0.029 & $\mathbf{0 . 7 0 8}$ & & & & & 0.501 & 0.751 \\
AI & 0.264 & 0.394 & 0.078 & $\mathbf{0 . 7 7 1}$ & & & & 0.594 & 0.813 \\
PT & 0.078 & 0.228 & 0.108 & 0.094 & $\mathbf{0 . 8 2 6}$ & & & 0.683 & 0.866 \\
PR & -0.054 & -0.022 & 0.024 & -0.011 & 0.009 & $\mathbf{0 . 8 2 6}$ & & 0.683 & 0.894 \\
SI & 0.005 & 0.087 & 0.008 & 0.016 & 0.006 & -0.007 & $\mathbf{0 . 7 8 0}$ & 0.609 & 0.747 \\
\hline
\end{tabular}

$A V E$, average variance extracted; $C R$, composite reliability; Off-diagonal elements are correlations, and the square root of the AVE value is indicated in italic and bold form

\begin{tabular}{llccccr}
\hline Statistic & $\chi^{2} / \mathrm{df}$ & \multicolumn{1}{c}{$\boldsymbol{p}$-value } & SRMR & RMSEA & GFI & \multicolumn{1}{c}{ IFI } \\
\hline Measurement model & 1.590 & 0.000 & 0.032 & 0.051 & 0.903 & 0.916 \\
Structural model & 1.677 & 0.000 & 0.034 & 0.055 & 0.898 & 0.901 \\
Recommended value & $<0.05$ & $p<0.001$ & $<0.08$ & $<0.08$ & $>0.900$ & $>0.900$ \\
Source & (Bentler and Bonett 1980; Hu and Bentler 1999a; Salisbury et al. 2002) & \\
\hline
\end{tabular}

$X^{2} / d f$, chi-square/degree of freedom; SRMR, standard root mean square residual; RMSEA, root mean square error of approximation; $G F I$, goodness-of-fit index; $I F I$, incremental fit index
Table 6 Model fit statistics for measurement and structural model 


\section{Structural equation modeling and hypotheses testing}

Following the validity and reliability analyses, the SEM was used to evaluate the study model of MFS adoption during the COVID-19 pandemic in Bangladesh based on sample data analysis. The results of the structural model fit indices were within the acceptable standard limits (Bentler and Bonett 1980; Hu and Bentler 1999b; Salisbury et al. 2002), as shown in Table 6 . The model fit indices are $\chi^{2} / \mathrm{df}=1.677, \mathrm{p}$-value $=0.000, \mathrm{SRMR}=0.034$, RMSEA $=0.055$, GFI $=0.898$, and IFI $=0.901$. The structural model of the study indicates the impact of the relation between latent variables and constructs, as highlighted in Fig. 5 and Table 7. The results indicated that PE $(\beta=0.455, p<0.001)$, EE $(\beta=0.254, p<0.001)$, and PR $(\beta=-0.169, p<0.05)$ were significantly correlated with the users' PV of adopting MFS platforms during the pandemic, corroborating hypotheses 1,2 and 3 . On the other hand, the PR of users was not found to be statistically significantly related to the adoption intention of MFS platforms $(\beta=0.057, p=0.536)$, indicating that hypothesis 4 was unsupported. The results further present the significant effect of PV on users' intention to adopt MFS platforms $(\beta=0.535, p<0.001)$, which corroborates hypothesis 5 . The path coefficient between PT and the intention of users to adopt MFS platforms was found to be statistically significant ( $\beta=0.153, p<0.10$ ), thus supporting hypothesis 6 . Finally, the results indicated that the SI positively influence users' adoption intention ( $\beta=0.173, p<0.10)$, thereby confirming hypothesis 7 .

Furthermore, respondents were asked to outline the primary reasons and objectives for utilizing MFS platforms. According to the findings presented in Fig. 6, over $41 \%$ of the respondents believe that MFS platforms were easier to use than internet banking, while roughly $25 \%$ believe MFS platforms are more cost-effective. On the other hand, almost $18 \%$ adopted mobile financial services due to the speed of delivery, followed by safety $(12.78 \%)$ and other reasons (3.08\%). Figure 7 highlights the purpose for the adoption of mobile banking services by users and empirical findings indicate that $20 \%$ of respondents utilized MFS platforms for savings and money transfers during the pandemic, followed by family groceries (18\%) and medical purposes (17\%). On the other hand, $10 \%$ used MFS platforms for mobile top-ups, while roughly $7 \%$ used them for educational, agricultural, and other purposes (3\%). The primary reasons for the adoption of mobile financial services in Bangladesh during the COVID-19 outbreak include easy access, costeffectiveness, fast service delivery, and safety. The main purpose for the adoption of MFS platforms include savings, money transfer, family shopping, medicals, mobile top-ups, education, and agriculture.

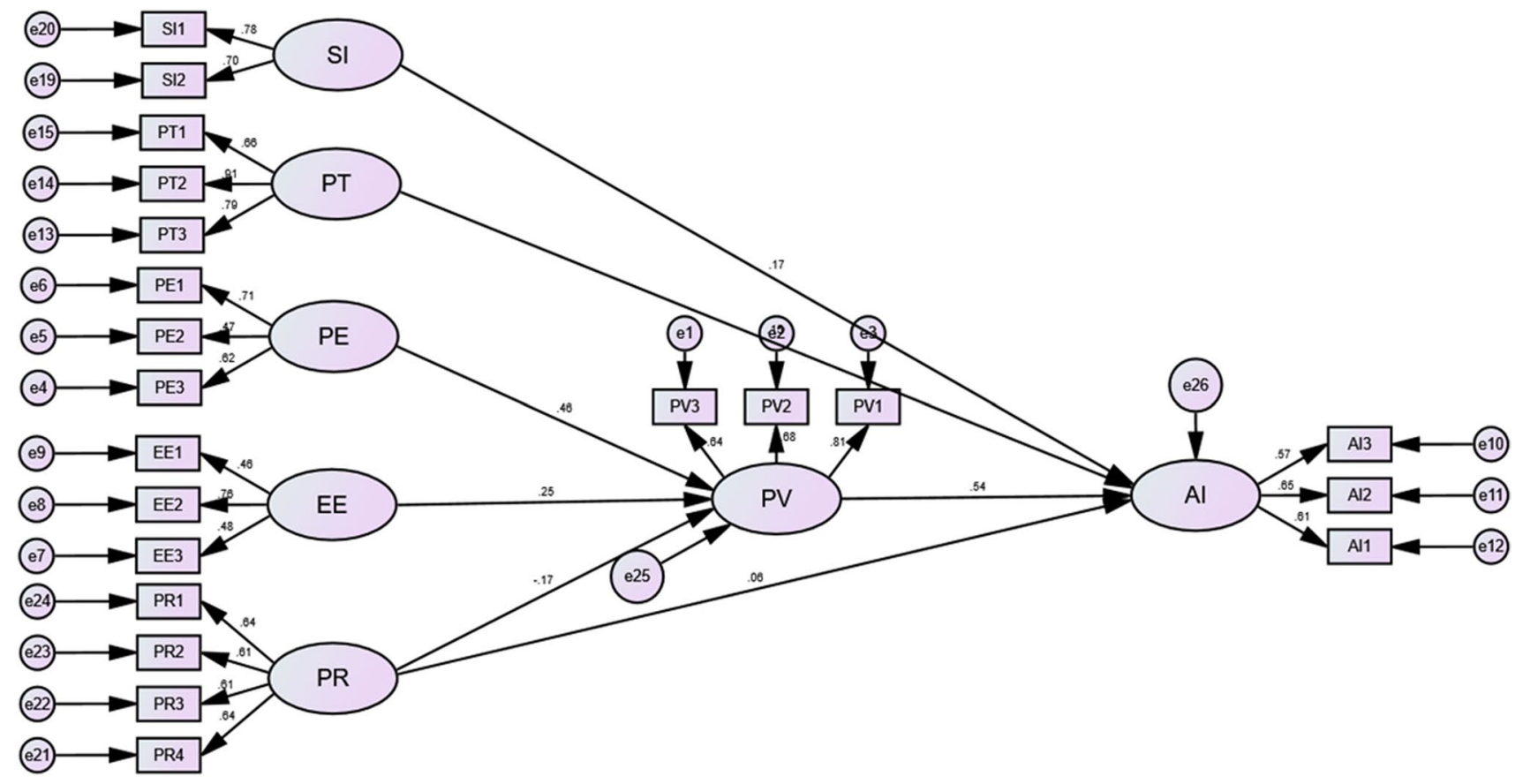

Fig. 5 Structural model of the study with standardized estimates 
Fig. 6 Reasons for using MFS platforms

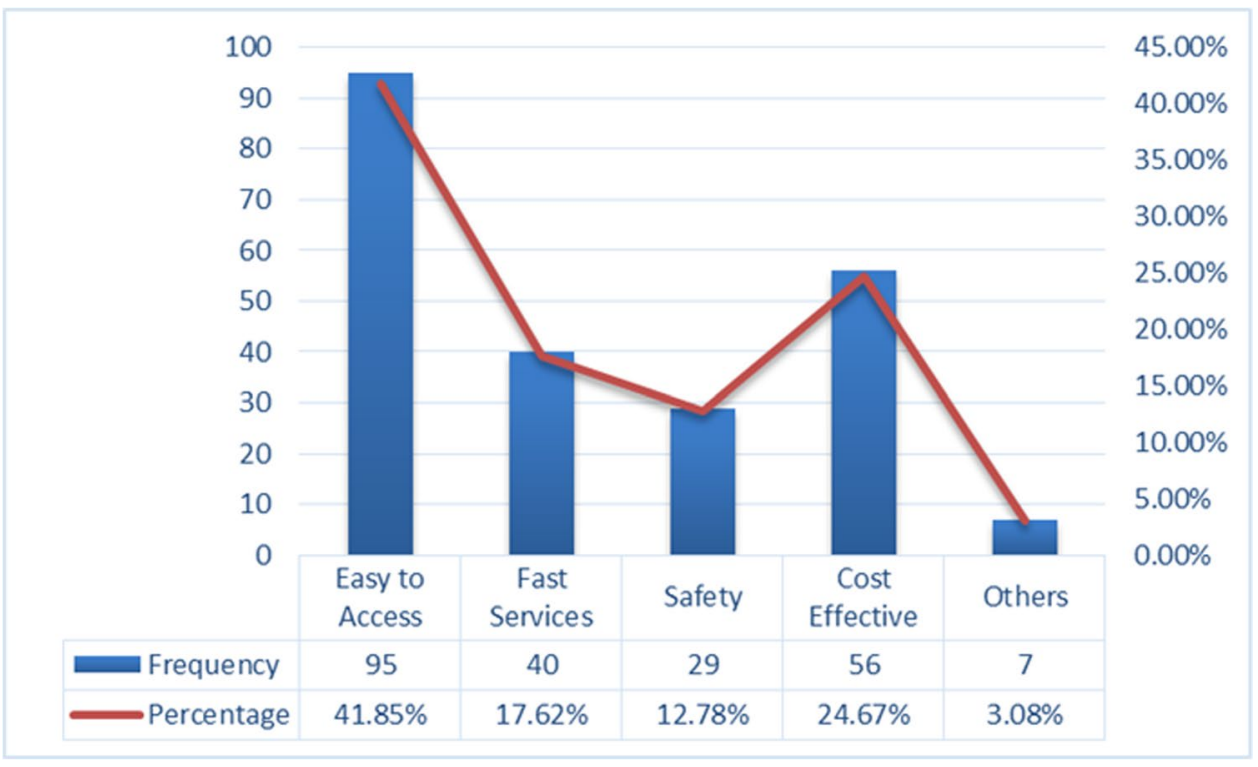

Fig. 7 Purpose of using MFS platforms

Table 7 Hypotheses results

\begin{tabular}{llcll}
\hline Hypotheses & Path & SE & $p$-value & Remarks \\
\hline Hypothesis 1 & PE ---> PV & $0.455^{* * *}$ & 0.000 & $\mathrm{H}_{1}$ is accepted. \\
Hypothesis 2 & EE ---> PV & $0.254^{* * *}$ & 0.009 & $\mathrm{H}_{2}$ is accepted. \\
Hypothesis 3 & PR ---> PV & $-0.169^{* *}$ & 0.044 & $\mathrm{H}_{3}$ is accepted. \\
Hypothesis 4 & PR ---> AI & 0.057 & 0.536 & $\mathrm{H}_{4}$ is not accepted. \\
Hypothesis 5 & PV ---> AI & $0.535^{* * *}$ & 0.000 & $\mathrm{H}_{5}$ is accepted. \\
Hypothesis 6 & PT ---> AI & $0.153^{*}$ & 0.062 & $\mathrm{H}_{6}$ is accepted. \\
Hypothesis 7 & SI ---> AI & $0.173^{*}$ & 0.082 & $\mathrm{H}_{7}$ is accepted. \\
\hline
\end{tabular}

$S E$, standardized estimate; $* * * p<0.01, * * p<0.05, * p<0.10$

\section{Discussion and conclusion}

The main aim of the study was to identify the factors influencing the intention of users in Bangladesh to adopt FinTech, particularly MFS platforms, during the COVID-19 pandemic. To achieve the research objective, the study combined social variables from the extended valence framework (e.g., trust and risk) and financial services consumption attributes like perceived value with the original UTAUT model and identified the main reasons and purposes for adopting MFS platforms during and after the Covid-19 outbreak in Bangladesh. The results of the study offer to explain the roles of MFS platforms in improving the resilience of the outbreak. The study employed SEM 
to test the research hypotheses. The empirical findings of the study showed that PT (H6), SI (H7), and PV (H5) positively influence the adoption intention, while PR (H4) was not statistically significantly related to users' adoption intention of MFS platforms during the pandemic. On the other hand, PR (H4), EE (H2), and PE (H1) were observed to have influenced the PV of users toward the adoption of MFS platforms during the outbreak.

Individuals' perceived value, which is influenced by PR, $\mathrm{PE}$, and EE, is a significant factor in the adoption of the MFS platform, and numerous studies have demonstrated that perceived value can be used to predict a consumer's intention to use the MFS platform (Gordon et al. 2018; Kim et al. 2007; Shaw and Sergueeva 2019; Xie et al. 2021). The study conducted by Shaw and Sergueeva (2019) validated the relationship between the PV and the adoption intention of mobile consumption (Shaw and Sergueeva 2019). The study of Xie et al. (2021) revealed a similar finding, confirming that PV directly affected users' intention to utilize FinTech services. Since our findings are supported by previously conducted studies (Shaw and Sergueeva 2019; Xie et al. 2021), it can be concluded that users in Bangladesh are more likely to use MFS platforms during and after the pandemic, if their $\mathrm{PV}$ is high.

Furthermore, the findings of the study indicated that the users' PR, PE, and EE influence the PV. This finding is consistent with the study of Xie et al. (2021), which cited similar findings. The utility of adopting MFS platforms could improve users' appraisal of the platform's worth since the $\mathrm{PE}$ of users had positively influenced the PV. Therefore, the higher the PV, the more useful and efficient the MFS platform provides. Simultaneously, the EE had a positive effect on the PV in this study, indicating that the degree of ease of use influences users' perceptions of the MFS platform. However, the PR was found to be negatively associated with the PV, reflecting the unpredictability of the consumption of financial services on MFS platforms.

According to empirical data, SI was observed to positively influence the adoption intention of MFS platforms by users, which is consistent with the UTAUT (Venkatesh et al. 2003, 2012). This finding is also supported by various studies in areas of FinTech and mobile banking (Al Nawayseh 2020; Queiroz and Fosso Wamba 2019; Sharma and Sharma 2019; Wei et al. 2021; Xie et al. 2021). However, some studies did not observe similar results (Baptista $\&$ Oliveira 2015; Shaw and Sergueeva 2019). Interestingly, the perceived risks of users did not influence their intention to use MFS platforms, which is supported by the previously conducted studies (Al Nawayseh 2020; Hu et al. 2019; Rouibah et al. 2016). However, this result contradicts previous research highlighting that perceived risks have a major impact on user intentions (Cao et al. 2018; Grover and Kar 2020; Liébana-Cabanillas et al. 2018; Ryu 2018; Stewart and
Jürjens 2018). This observation can be attributed to the fact that consumers' fear of technology hazards was masked by their anxieties during the COVID-19 epidemic, particularly in developing countries. Additionally, research demonstrates that consumers' intent to adopt FinTech services such as mobile banking are more affected by their perceived value rather than perceived risks.

Finally, the results of the study indicated that the PT positively affects the intention of Bangladeshi users to adopt MFS platforms during the COVID-19 pandemic. Thus, our findings are corroborated by other research, which confirms that people's perceived trust is one of the most important elements influencing their inclination toward the adoption of a new technology (Cao et al. 2018; Malaquias and Hwang 2016; Rouibah et al. 2016; Xin et al. 2015; Q. Yang et al. 2015). Therefore, it can be inferred that users' PT plays a critical role in the adoption of new technologies such as FinTech in the context of emerging economies during and after a pandemic crisis.

\section{Theoretical and practical implications of the study}

\section{Theoretical implications}

The present study developed a comprehensive model based on the UTAUT that incorporates financial services consumption attributes like PV with additional contextual aspects from the extended valence framework such as PT and PR to predict users' adoption intention of MFS during the COVID19 pandemic in the context of emerging economies. It should be noted that the new structures, namely user trust, perceived value, and risk are consistent with the UTAUT. Since these three elements have been previously explored independently in prior studies, they were verified concurrently in the MFS platforms during the viral outbreak. During the pandemic, the proposed model gives a comprehensive framework for an understanding of MFS usage and expands the UTAUT to the FinTech sector. The suggested model is significant for assessing the behavioral intention of MFS platforms, as it examines the adoption of MFS by users in relation to their financial services consumption and technology usage perspectives. Furthermore, the connections between the UTAUT components and the new elements were confirmed in the context of mobile banking.

By incorporating PV and PR with the basic concept of UTAUT, this study gives a complete viewpoint to evaluate the acceptance of MFS during the COVID-19 pandemic. The study discovered that the perceived risk did not influence the users' intention to adopt MFS platforms during the pandemic, as supported by the study of Al Nawayseh (2020). The study, on the other hand, confirmed that the perceived 
value had a considerable influence on users' intention of using MFS platforms during the outbreak. In this regard, users prioritize the adoption of the MFS platform during a pandemic based on the perceived platform value rather than perceived risk, which could strengthen the understanding of the theoretical framework in our setting. Moreover, the present study expands the UTAUT, suggesting that PE and EE indirectly affect the intention of users to adopt MFS platforms during the pandemic. Therefore, by elucidating the relationship between PE, EE and PV, the UTAUT has been further developed in the FinTech domain, particularly in MFS platforms, in emerging countries like Bangladesh, during the pandemic crisis.

\section{Practical implications}

The current study has significant practical policy implications on MFS offered by diverse organizations, such as banks, government-owned enterprises, non-bank financial institutions, as can be shown in Figure 8. First, the study discovered that the PE and EE significantly influence the $\mathrm{PV}$ of users toward the adoption of MFS platforms during the pandemic. This finding can be applied to the design of user interfaces and sales marketing during and after a pandemic crisis in an emerging economy like Bangladesh. MFS providers can increase consumers' PV of mobile banking by making their systems more useful and easier to use. On the contrary, MFS providers should strive to simplify the user operation procedures and interface, including registration, installation, and transactions. For instance, MFS providers may implement a fingerprint or facial recognition system to enable users to $\log$ in to mobile applications. In this regard, the performance expectancy and perceived value of users of MFS platforms will improve during and after the pandemic.
Interestingly, the results of the study showed that PR did not influence users' intention to adopt MFS platforms during the pandemic. This result is justified by the observation that users' anxieties during the COVID-19 epidemic got the better of them, and as a result, the technology risks were overshadowed by their fears, in the context of emerging economies like Bangladesh. Further, this finding also demonstrates that users' intention to adopt FinTech services such as mobile banking is more affected by their perceived value than perceived risks. Therefore, MFS providers should not ignore the risks associated with their products and services, but should instead, raise security awareness and work on developing risk-free MFS platforms, as users will continue to have similar worries after the pandemic. Additionally, MFS providers may offer insurance in conjunction with the availability of financial services via mobile banking applications. Furthermore, MFS providers could employ advanced data encryption techniques like facial recognition to improve the safety and security of the mobile financial services they provide.

The findings of the study also indicated that SI positively effects users' intention to adopt MFS platforms during the pandemic. This result may assist MFS providers in developing a successful marketing plan. For example, MFS providers may collaborate with various social media platforms (e.g., Facebook, Twitter, IMO and WhatsApp) to enable users to share MFS with their family members and friends, and show the number of friends using the service on the application dashboard. MFS providers may also employ similar strategies to acquire new customers to participate in a sales promotion. Overall, the findings have major implications for both insiders and new entrants intending to increase their competitiveness and adopt related policies in their MFS launch.
Fig. 8 Future policy implications for the development of the MFS during and after the COVID-19 pandemic

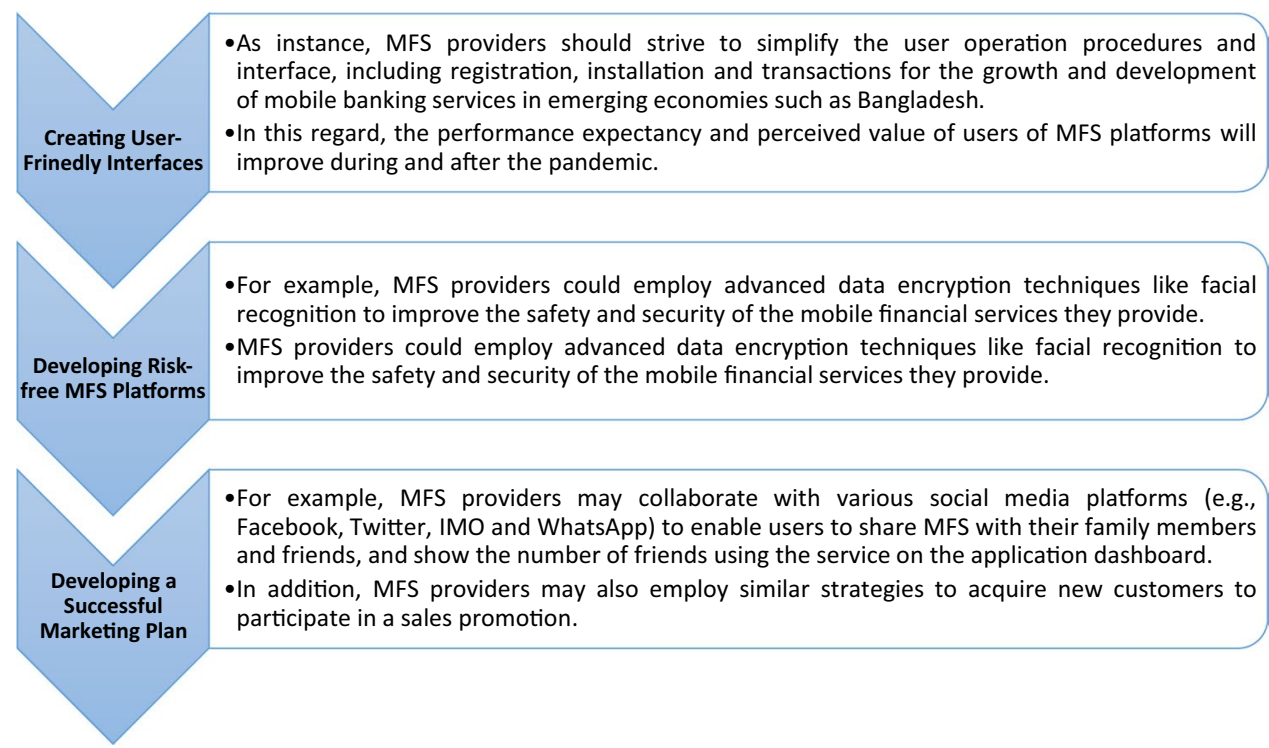




\section{Study limitations and future research}

This study is regarded as one of the earliest to empirically scrutinize the role of MFS during the COVID-19 pandemic in the context of an emerging economy like Bangladesh. Although this survey delivers some valuable contributions, it has some limitations. First, the study was conducted using data from Bangladeshi customers, which is a tiny sample size compared to the overall mobile usage adoption, thereby restricting the generalization of the results in terms of randomization and cultural differences. Therefore, the findings of this study could be enhanced in terms of generalization by examining different developing nations and increasing the sample size. Second, the moderation effects of the demographic factors of users (e.g., age, gender and experience) were not examined in this study. Thus, the moderators could be included in future studies to investigate the moderating impact of user characteristics on the developed framework. Besides, other elements such as user innovativeness, environmental factors, and technological knowledge, as well as the impact of government laws on MFS adoption may be the subject of future research. Subsequent research should examine these issues and expand on the findings of this exploratory research to better understand the acceptance of MFS and their real application in Bangladesh and other scenarios.

Acknowledgements The researchers would like to express their gratitude to the anonymous reviewers for their efforts to improve the quality of this paper.

Author contribution Conceptualization, A.B.S.; methodology, A.B.S., C.Y., and N.A.; software, A.B.S. and C.Y.; validation, C.Y., A.B.S., and N.A.; investigation, N.A., A.B.S. and C.Y.; resources, A.B.S. and N.A.; data curation, N.A., and A.B.S.; writ-ing-original draft preparation, A.B.S., and C.Y.; writing-review and editing, C.Y., and Q.D., A.B.S.; visualization, A.B.S. and N.A., ; supervision, Q.D., and N.A.; Funding ac-quisition, C.Y. All authors have read and agreed to the published version of the manuscript.

Funding This research was funded by the Key Project of the National Social Science Foundation of China (grant no. 20AJY015), and the Fundamental Research Funds for the Central Universities (grant no.300102341667).

Data availability The data that support the findings of this study are available from the corresponding authors (A.B.S) upon reasonable request.

\section{Declarations}

Ethics approval and consent to participate Not applicable

Consent for publication Not applicable

Competing interests The authors declare no competing of interests.

\section{References}

Abdullah EME, Rahman AA, Rahim R (2018) Adoption of financial technology (Fintech) in mutual fund/unit trust investment among Malaysians: unified theory of acceptance and use of technology (UTAUT). Int J Eng Technol 7:110-118

Adaba GB, Ayoung DA, Abbott P (2019) Exploring the contribution of mobile money to well-being from a capability perspective. Electron J Inf Syst Dev Countries 85(4):e12079. https://doi. org/10.1002/isd2.12079

Aji HM, Berakon I, Husin MM (2020) COVID-19 and e-wallet usage intention: a multigroup analysis between Indonesia and Malaysia. Cogent Bus Manag 7(1):1804181. https://doi.org/10.1080/ 23311975.2020.1804181

Ajzen I (1991) The theory of planned behavior. Organ Behav Hum Decis Process 50(2):179-211. https://doi.org/10.1016/07495978(91)90020-T

Al-Maroof RS, Salloum SA, Hassanien AE, Shaalan K (2020) Fear from COVID-19 and technology adoption: the impact of Google Meet during Coronavirus pandemic. Interactive Learning Environments, 0(0), 1-16. https://doi.org/10.1080/10494 820.2020 .1830121

Al Nawayseh MK (2020) Fintech in COVID-19 and beyond: what factors are affecting customers' choice of fintech applications? J Open Innov: Technol Mark Complex 6(4):1-15. https://doi. org/10.3390/joitmc6040153

Alalwan AA, Dwivedi YK, Rana NP, Algharabat R (2018) Examining factors influencing Jordanian customers' intentions and adoption of internet banking: extending UTAUT2 with risk. J Retail Consum Serv 40(August 2017):125-138. https://doi.org/ 10.1016/j.jretconser.2017.08.026

Ameen N, Shah MH, Sims J, Choudrie J, Willis R (2020) Are there peas in a pod when considering mobile phone and mobile applications use: a quantitative study. J Retail Consum Serv 55:102067. https://doi.org/10.1016/j.jretconser.2020.102067

Amidjaya PG, Widagdo AK (2020) Sustainability reporting in Indonesian listed banks. J Appl Acc Res 21(2):231-247. https://doi. org/10.1108/JAAR-09-2018-0149

Arevian AC, O'Hora J, Jones F, Mango J, Jones L, Williams PG, Booker-Vaughns J, Jones A, Pulido E, Banner-Jackson D, Wells KB (2018) Participatory technology development to enhance community resilience. Ethn Dis 28(Suppl 2):493-502. https://doi.org/10.18865/ed.28.S2.493

Arias-Oliva M, Pelegrín-Borondo J, Matías-Clavero G (2019) Variables influencing cryptocurrency use: a technology acceptance model in Spain. Front Psychol 10:475. https://doi.org/10.3389/ fpsyg.2019.00475

Arner DW, Barberis JN, Buckley RP (2015) The Evolution of Fintech: A New Post-Crisis Paradigm? https://doi.org/10.2139/ ssrn.2676553

Azad MAK (2016) Predicting mobile banking adoption in Bangladesh: a neural network approach. Transl Corp Rev 8(3):207214. https://doi.org/10.1080/19186444.2016.1233726

Bailey JE, Pearson SW (1983) Development of a tool for measuring and analyzing computer user satisfaction. Manage Sci 29(5):530-545. https://doi.org/10.1287/mnsc.29.5.530

Baptista G, Oliveira T (2015) Understanding mobile banking: the unified theory of acceptance and use of technology combined with cultural moderators. Comput Hum Behav 50:418-430. https://doi.org/10.1016/j.chb.2015.04.024

Basak SK, Govender D, Govender I (2016) Examining the impact of privacy, security, and trust on the TAM and TTF models for e-commerce consumers: a pilot study. 2016 14th Annual Conference on Privacy, Security and Trust (PST), pp 19-26 
Beach LR, Mitchell TR (1978) A contingency model for the selection of decision strategies. Acad Manag Rev 3(3):439-449. https:// doi.org/10.5465/amr.1978.4305717

Beldad AD, Hegner SM (2018) Expanding the technology acceptance model with the inclusion of trust, social influence, and health valuation to determine the predictors of german users' willingness to continue using a fitness app: a structural equation modeling approach. Int J Hum Comput Interact 34(9):882-893. https://doi. org/10.1080/10447318.2017.1403220

Bentler PM, Bonett DG (1980) Significance tests and goodness of fit in the analysis of covariance structures. Psychol Bull 88(3):588606. https://doi.org/10.1037/0033-2909.88.3.588

Bharadwaj PN, Jack W, Suri T (2019) Fintech and household resilience to shocks: evidence from digital loans in Kenya. PSN: Infrastructure $\backslash \&$ Communication (Topic). https://ssrn.com/abstract= 3346223

Biswas AU (2021) Top Mobile Financial Services (MFS) in Bangladesh. Businesshaunt. https://www.businesshaunt.com/mobilefinancial-services-mfs-in-bangladesh/. Accessed 25 June 2021

Sreelakshmi CC, Prathap SK (2020) Continuance adoption of mobilebased payments in Covid-19 context: an integrated framework of health belief model and expectation confirmation model. Int $\mathbf{J}$ Pervasive Comput Commun 16(4):351-369. https://doi.org/10. 1108/IJPCC-06-2020-0069

Cao X, Yu L, Liu Z, Gong M, Adeel L (2018) Understanding mobile payment users' continuance intention: a trust transfer perspective. Internet Res 28(2):456-476. https://doi.org/10.1108/ IntR-11-2016-0359

Chen L (2016) From Fintech to Finlife: the case of Fintech development in China. China Econ J 9(3):225-239. https://doi.org/10. 1080/17538963.2016.1215057

Chen MA, Wu Q, Yang B (2019) How valuable is FinTech innovation? Rev Financ Stud 32(5):2062-2106. https://doi.org/10.1093/rfs/ hhy 130

Chiu C-M, Wang ETG, Fang Y-H, Huang H-Y (2014) Understanding customers' repeat purchase intentions in $\mathrm{B} 2 \mathrm{C}$ e-commerce: the roles of utilitarian value, hedonic value and perceived risk. Inf Syst J 24(1):85-114. https://doi.org/10.1111/j.1365-2575.2012. 00407.x

Chiu Y-TH, Lee W-I, Liu C-C, Liu L-Y (2012) Internet lottery commerce: an integrated view of online sport lottery adoption. $\mathrm{J}$ Internet Commer 11(1):68-80. https://doi.org/10.1080/15332 861.2012 .650990

Dalim SH (2020) Silent role of MFS to keep the economy going. The Daily Star. https://www.thedailystar.net/opinion/econo mics/news/silent-role-mfs-keep-the-economy-going-1890613. Accessed 24 June 2021

Daragmeh A, Sági J, Zéman Z (2021) Continuous Intention to use E-wallet in the context of the COVID-19 pandemic: integrating the Health Belief Model (HBM) and Technology Continuous Theory (TCT). J Open Innov: Technol Mark Complex 7(2). https://doi.org/10.3390/joitmc7020132

Dávid V (2017) Fintech, the new era of financial services. Vezetéstudomány - Budapest Manag Rev 48(11):22-32. https://doi.org/10. 14267/VEZTUD.2017.11.03

Davis FD (1985) A technology acceptance model for empirically testing new end-user information systems : theory and results.Massachusetts Institute of Technology

Davis FD, Bagozzi R, Warshaw PR (1989) User acceptance of computer technology: a comparison of two theoretical models. Manage Sci 35:982-1003

de Luna IR, Liébana-Cabanillas F, Sánchez-Fernández J, Muñoz-Leiva F (2019) Mobile payment is not all the same: the adoption of mobile payment systems depending on the technology applied. Technol Forecast Soc Chang 146:931-944. https://doi.org/10. 1016/j.techfore.2018.09.018 de SenaAbrahão R, Moriguchi SN, Andrade DF (2016) Intention of adoption of mobile payment: an analysis in the light of the Unified Theory of Acceptance and Use of Technology (UTAUT). RAI Rev Adm Inovação 13(3):221-230. https://doi.org/10. 1016/j.rai.2016.06.003

DeLone WH, McLean E (2003) The DeLone and McLean model of information systems success: a ten-year update. J Manag Inf Syst 19:9-30

DesJardine M, Bansal P, Yang Y (2019) Bouncing back: building resilience through social and environmental practices in the context of the 2008 Global Financial Crisis. J Manag 45(4):1434-1460. https://doi.org/10.1177/0149206317708854

Dhar V, Stein RM (2017) FinTech platforms and strategy. Commun ACM 60(10):32-35. https://doi.org/10.1145/3132726

Duane A, O'Reilly P, Andreev P (2014) Realising M-Payments: modelling consumers' willingness to M-pay using Smart Phones. Behav Inform Technol 33(4):318-334. https://doi.org/10.1080/ 0144929X.2012.745608

Fishbein M, Ajzen I (1977) Belief, attitude, intention, and behavior: an introduction to theory and research. Contemp Sociol 6:244

Fornell C, Larcker DF (1981) Evaluating structural equation models with unobservable variables and measurement error. J Mark Res 18(1):39. https://doi.org/10.2307/3151312

Gefen D, Rigdon EE, Straub D (2011) Editor's comments: an update and extension to SEM guidelines for administrative and social science research. MIS Q 35(2):iii-xiv. https://doi.org/10.2307/ 23044042

Gomber P, Kauffman RJ, Parker C, Weber BW (2018) On the Fintech revolution: interpreting the forces of innovation, disruption, and transformation in financial services. J Manag Inf Syst 35(1):220-265. https://doi.org/10.1080/07421222.2018.14407 66

Goo JJ, Heo J-Y (2020) The impact of the regulatory sandbox on the Fintech industry, with a discussion on the relation between regulatory sandboxes and open innovation. J Open Innov: Technol Mark Complex 6(2). https://doi.org/10.3390/joitmc6020043

Gordon R, Dibb S, Magee C, Cooper P, Waitt G (2018) Empirically testing the concept of value-in-behavior and its relevance for social marketing. J Bus Res 82:56-67. https://doi.org/10.1016/j. jbusres.2017.08.035

Grover P, Kar AK (2020) User engagement for mobile payment service providers - introducing the social media engagement model. J Retail Consum Serv 53:101718. https://doi.org/10.1016/j.jretc onser.2018.12.002

Hair JF, Black WC, Babin BJ, Anderson RE (2010) Multivariate Data Analysis, 4 edn. Prentice Hall

Harrison PJ (2021) The Growth of contactless payments during the Covid-19 pandemic. The Financial Times. https://thefintech times.com/the-growth-of-contactless-payments-during-thecovid-19-pandemic/

Heeks R, Ospina AV (2019) Conceptualising the link between information systems and resilience: a developing country field study. Inform Syst J 29(1):70-96. https://doi.org/10.1111/isj.12177

Holy IJ (2020) Mobile Financial Services: acceleration in digital transactions amidst COVID-19. LightCastle Analytics Wing. https:// www.lightcastlebd.com/insights/2020/06/mobile-financialservices-acceleration-in-digital-transactions-amidst-covid-19. Accessed 22 June 2021

Hu LT, Bentler PM (1999a) Cutoff criteria for fit indexes in covariance structure analysis: conventional criteria versus new alternatives. Struct Equ Model. https://doi.org/10.1080/10705519909540118

$\mathrm{Hu}$ LT, Bentler PM (1999b) Cutoff criteria for fit indexes in covariance structure analysis: conventional criteria versus new alternatives. Struct Equ Model 6(1):1-55. https://doi.org/10.1080/10705 519909540118 
Hu Z, Ding S, Li S, Chen L, Yang S (2019) Adoption intention of fintech services for bank users: an empirical examination with an extended technology acceptance model. Symmetry 11(3). https:// doi.org/10.3390/sym 11030340

Hussain AHMB, Endut N, Das S, Chowdhury MTA, Haque N, Sultana S, Ahmed KJ (2019) Does financial inclusion increase financial resilience? Evidence from Bangladesh. Dev Pract 29(6):798-807. https://doi.org/10.1080/09614524.2019.16072 56

Islam MN (2021) Impact of COVID-19 in digital payment and factors that will drive digital payment in coming day. Banglanews24.Com. https://www.banglanews24.com/english/busin ess/news/bd/87991.details. Accessed 25 June 2021

Jiang Y, (Chad) Ho Y-C, Yan X, Tan Y (2018) Investor platform choice: herding, platform attributes, and regulations. J Manag Inf Syst 35(1):86-116. https://doi.org/10.1080/07421222.2018.1440770

Johnson EJ, Payne JW (1985) Effort and accuracy in choice. Manage Sci 31(4):395-414. https://doi.org/10.1287/mnsc.31.4.395

Jonker M, de Bekker-Grob E, Veldwijk J, Goossens L, Bour S, RuttenVan Mölken M (2020) COVID-19 contact tracing apps: predicted uptake in the Netherlands based on a discrete choice experiment. JMIR Mhealth Uhealth 8(10):e20741. https://doi.org/10.2196/ 20741

Kabir MR, Islam MA, Marniati, \& Herawati (2021) Application of blockchain for supply chain financing: explaining the drivers using SEM. J Open Innovation: Tech Market Complexity 7(3):167. https://doi.org/10.3390/joitmc7030167

Karagiannaki A, Vergados G, Fouskas KG (2017) The impact of digital transformation in the financial services industry: insights from an open innovation initiative in Fintech in Greece. MCIS Proceedings. 2. Available at http://aisel.aisnet.org/mcis2017/2

Karusala N, Holeman I, Anderson R (2019) Engaging identity, assets, and constraints in designing for resilience. Proc ACM Hum Comput Interact 3(CSCW). https://doi.org/10.1145/3359315

Kesharwani A, Singh Bisht S (2012) The impact of trust and perceived risk on internet banking adoption in India. Int J Bank Mark 30(4):303-322. https://doi.org/10.1108/02652321211236923

Khatun MN, Mitra S, Sarker MNI (2021) Mobile banking during COVID-19 pandemic in Bangladesh: a novel mechanism to change and accelerate people's financial access. Green Finance 3(3):253-267. https://doi.org/10.3934/gf.2021013

Khatun N, Tamanna M (2020) Factors affecting the adoption of Fintech: a study based on the financial institutions in Bangladesh. Copernican J Financ Account 9(4):51-75. https://doi.org/10. 12775/CJFA.2020.021

Kim DJ, Ferrin DL, Rao HR (2008) A trust-based consumer decisionmaking model in electronic commerce: the role of trust, perceived risk, and their antecedents. Decis Support Syst 44(2):544564. https://doi.org/10.1016/j.dss.2007.07.001

Kim H-W, Chan HC, Gupta S (2007) Value-based adoption of mobile internet: an empirical investigation. Decis Support Syst 43(1):111-126. https://doi.org/10.1016/j.dss.2005.05.009

Kingiri AN, Fu X (2020) Understanding the diffusion and adoption of digital finance innovation in emerging economies: M-Pesa money mobile transfer service in Kenya. Innov Dev 10(1):67-87. https://doi.org/10.1080/2157930X.2019.1570695

Koksal MH (2016) The intentions of Lebanese consumers to adopt mobile banking. Int J Bank Mark 34(3):327-346. https://doi.org/ 10.1108/IJBM-03-2015-0025

Liao C, Liu C-C, Chen K (2011) Examining the impact of privacy, trust and risk perceptions beyond monetary transactions: an integrated model. Electron Commer Res Appl 10(6):702-715. https://doi. org/10.1016/j.elerap.2011.07.003

Liébana-Cabanillas F, Muñoz-Leiva F, Sánchez-Fernández J (2018) A global approach to the analysis of user behavior in mobile payment systems in the new electronic environment. Serv Bus $12: 25-64$

Liu Y, Wang M, Huang D, Huang Q, Yang H, Li Z (2019) The impact of mobility, risk, and cost on the users' intention to adopt mobile payments. IseB 17(2):319-342. https://doi.org/10.1007/ s10257-019-00449-0

Malaquias RF, Hwang Y (2016) An empirical study on trust in mobile banking: a developing country perspective. Comput Hum Behav $54: 453-461$

Murtuza H (2020) No of MFS users rises by 60 lakh in July-Sept amid COVID-19. Business Age. https://www.newagebd.net/article/ 120733/no-of-mfs-users-rises-by-60-lakh-in-july-sept-amid-covid-19

Pal A, De' R, Herath T (2020) The role of mobile payment technology in sustainable and human-centric development: evidence from the postdemonetization period in India. Inf Syst Front 22(3):607-631. https:// doi.org/10.1007/s10796-020-09982-7

Pal A, De' R, Herath T, Rao HR (2019) A review of contextual factors affecting mobile payment adoption and use. J Bank Financial Technol 3(1):43-57. https://doi.org/10.1007/ s42786-018-00005-3

Patil PP, Rana NP, Dwivedi YK, Abu-Hamour H (2018) The role of trust and risk in mobile payments adoption: a meta-analytic review. PACIS

Pavlou PA (2003) Consumer acceptance of electronic commerce: integrating trust and risk with the technology acceptance model. Int J Electron Commer 7(3):101-134. https://doi.org/10.1080/10864 415.2003.11044275

Payne JW (1982) Contingent decision behavior. Psychol Bull 92(2):382-402. https://doi.org/10.1037/0033-2909.92.2.382

Peter JP, Ryan MJ (1976) An Investigation of Perceived Risk at the Brand Level. J Mark Res 13:184-188. https://doi.org/10.1177/ 002224377601300210

Prasetyo YT, Tanto H, Mariyanto M, Hanjaya C, Young MN, Persada SF, Miraja BA, Redi AANP (2021) Factors affecting customer satisfaction and loyalty in online food delivery service during the COVID-19 pandemic: its relation with open innovation. J Open Innov: Technol Mark Complex 7(1). https://doi.org/10. 3390/joitmc7010076

Puriwat W, Tripopsakul S (2021) Explaining an adoption and continuance intention to use contactless payment technologies: during the covid-19 pandemic. Emerg Sci J 5(1):85-95. https://doi.org/ 10.28991/esj-2021-01260

Puschmann T (2017) Fintech. Bus Inform Syst Eng 59(1):69-76. https://doi.org/10.1007/s12599-017-0464-6

Rahi S, Khan MM, Alghizzawi M (2021) Factors influencing the adoption of telemedicine health services during COVID-19 pandemic crisis: an integrative research model. Enterp Inform Syst 15(6):769-793. https://doi.org/10.1080/17517575.2020.1850872

Queiroz MM, FossoWamba S (2019) Blockchain adoption challenges in supply chain: an empirical investigation of the main drivers in India and the USA. Int J Inform Manag 46:70-82. https://doi. org/10.1016/j.ijinfomgt.2018.11.021

Rahman MF (2021) The future of mobile financial services in Bangladesh. The Daily Star. https://www.thedailystar.net/supplements/ mobile-financial-services/news/the-future-mobile-financial-servi ces-bangladesh-2028885. Accessed 24 June 2021

Rahman Z (2020) As MFS grows, its regulations need to change. The Business Standard. https://www.tbsnews.net/thoughts/mfsgrows-its-regulations-need-change-136069. Accessed 24 June 2021

Reich G (2021) Online and mobile banking adoption soars, setting new benchmarks for 2021. The Financial Brand. https://thefi nancialbrand.com/107582/garret-online-mobile-banking-adopt ion-rates-covid/. Accessed 23 June 2021

Rizun M, Strzelecki A (2020) Students' acceptance of the COVID19 impact on shifting higher education to distance learning in 
Poland. Int J Environ Res Pub Health 17(18). https://doi.org/10. 3390/ijerph17186468

Rogers E, Simon, Schuster (2003) Diffusion of Innovations, 5th edn

Rouibah K, Lowry PB, Hwang Y (2016) The effects of perceived enjoyment and perceived risks on trust formation and intentions to use online payment systems: new perspectives from an Arab country. Electron Commer Res Appl 19:33-43. https://doi.org/ 10.1016/j.elerap.2016.07.001

Roy A (2016) Strategic social marketing. J Int Consum Mark 28(1):7374. https://doi.org/10.1080/08961530.2015.1089120

Ruiz-Real JL, Nievas-Soriano BJ, Uribe-Toril J (2020) Has Covid19 gone viral? An overview of research by subject area. Health Educ Behav 47(6):861-869. https://doi.org/10.1177/1090198120 958368

Ryu H-S (2018) What makes users willing or hesitant to use Fintech?: the moderating effect of user type. Ind Manag Data Syst 118(3):541-569. https://doi.org/10.1108/IMDS-07-2017-0325

Salem M, Nor K (2020) The effect of COVID-19 on consumer behaviour in Saudi Arabia: switching from brick and mortar stores to E-commerce. Int J Sci Technol Res 9:15-28

Salisbury WD, Chin WW, Gopal A, Newsted PR (2002) Research report: better theory through measurement-developing a scale to capture consensus on appropriation. Inf Syst Res 13(1):91103. https://doi.org/10.1287/isre.13.1.91.93

Salloum SA, Al-Emran M, Shaalan K (2018) The impact of knowledge sharing on information systems: a review. In: Uden L, Hadzima B, Ting I-H (eds) Knowledge Management in Organizations. Springer International Publishing, pp 94-106

Senyo PK, Osabutey ELC (2020) Unearthing antecedents to financial inclusion through FinTech innovations. Technovation 98:102155. https://doi.org/10.1016/j.technovation.2020.102155

Shahabi V, Azar A, FaezyRazi F, Fallah Shams MF (2021) Simulation of the effect of COVID-19 outbreak on the development of branchless banking in Iran: case study of Resalat Qard-al-Hasan Bank. Rev Behav Finance 13(1):85-108. https://doi.org/10.1108/ RBF-06-2020-0123

Shaikh IM, Qureshi MA, Noordin K, Shaikh JM, Khan A, Shahbaz MS (2020) Acceptance of Islamic financial technology (FinTech) banking services by Malaysian users: an extension of technology acceptance model. Foresight 22(3):367-383. https://doi.org/10. 1108/FS-12-2019-0105

Shakila CT (2021) Impact of pandemic COVID-19 in the Mobile Banking Sector of Bangladesh. IOSR J Bus Manag (IOSR-JBM) 23(6):07-12

Sharifi A, Ahmadi M, Ala A (2021) The impact of artificial intelligence and digital style on industry and energy post-COVID-19 pandemic. Environ Sci Pollut Res 28(34):46964-46984. https:// doi.org/10.1007/s11356-021-15292-5

Sharma R, Singh G, Sharma S (2020) Modelling internet banking adoption in Fiji: a developing country perspective. Int J Inf Manage 53(March):102116. https://doi.org/10.1016/j.ijinfomgt.2020. 102116

Sharma SK, Sharma M (2019) Examining the role of trust and quality dimensions in the actual usage of mobile banking services: an empirical investigation. Int J Inform Manag 44(July 2018):65-75. https://doi.org/10.1016/j.ijinfomgt.2018.09.013

Shaw N, Sergueeva K (2019) The non-monetary benefits of mobile commerce: extending UTAUT2 with perceived value. Int $\mathbf{J}$ Inform Manag 45:44-55. https://doi.org/10.1016/j.ijinfomgt. 2018.10.024

Sirdeshmukh D, Singh J, Sabol B (2002) Consumer trust, value, and loyalty in relational exchanges. J Mark 66(1):15-37. https://doi. org/10.1509/jmkg.66.1.15.18449

Slade EL, Dwivedi YK, Piercy NC, Williams MD (2015) Modeling consumers' adoption intentions of remote mobile payments in the United Kingdom: extending UTAUT with innovativeness, risk, and trust. Psych Mark 32(8):860-873. https://doi.org/10. $1002 /$ mar.20823

Stewart H, Jürjens J (2018) Data security and consumer trust in FinTech innovation in Germany. Inform Comput Secur 26(1):109128. https://doi.org/10.1108/ICS-06-2017-0039

Sudarsono H, Nugrohowatir RNI, Tumewang YK (2020) The effect of Covid-19 pandemic on the adoption of internet banking in Indonesia: Islamic Bank and Conventional Bank. J Asian Finance Econ Bus 7(11):789-800

Sultana B, Khan MR (2017) Are Mobile Financial Services Promoting Financial Inclusion in Bangladesh? An Assessment Study

Tabetando R, Matsumoto T (2020) Mobile money, risk sharing, and educational investment: panel evidence from rural Uganda. Rev Dev Econ 24(1):84-105. https://doi.org/10.1111/rode.12644

Thakur R, Srivastava M (2014) Adoption readiness, personal innovativeness, perceived risk and usage intention across customer groups for mobile payment services in India. Internet Res 24(3):369-392. https://doi.org/10.1108/IntR-12-2012-0244

Venkatesh V, Davis FD (2000) A Theoretical Extension of the Technology Acceptance Model: Four Longitudinal Field Studies.: Four Longitudinal Field Studies

Venkatesh V, Morris MG, Davis GB, Davis FD (2003) User acceptance of information technology: toward a unified view. MIS Q 27(3):425-478. https://doi.org/10.2307/30036540

Venkatesh V, Thong JYL, Xu X (2012) Consumer acceptance and use of information technology: extending the unified theory of acceptance and use of technology. MIS Q 36(1):157-178. https:// doi.org/10.2307/41410412

Wei M-F, Luh Y-H, Huang Y-H, Chang Y-C (2021) Young generation's mobile payment adoption behavior: analysis based on an extended UTAUT model. J Theor Appl Electron Commer Res 16(4):618-637. https://doi.org/10.3390/jtaer16040037

Xie J, Ye L, Huang W, Ye M (2021) Understanding FinTech platform adoption: impacts of perceived value and perceived risk. J Theor Appl Electron Commer Res 16(5):1893-1911. https://doi.org/10. 3390/jtaer16050106

Xin H, Techatassanasoontorn AA, Tan FB (2015) Antecedents of consumer trust in mobile payment adoption. J Comput Inform Syst 55(4):1-10. https://doi.org/10.1080/08874417.2015.11645781

Yang Q, Pang C, Liu L, Yen DC, Michael Tarn J (2015) Exploring consumer perceived risk and trust for online payments: an empirical study in China's younger generation. Comput Hum Behav 50:9-24. https://doi.org/10.1016/j.chb.2015.03.058

Yang S, Lu Y, Gupta S, Cao Y, Zhang R (2012) Mobile payment services adoption across time: an empirical study of the effects of behavioral beliefs, social influences, and personal traits. Comput Hum Behav 28(1):129-142. https://doi.org/10.1016/j.chb.2011. 08.019

Younus S, Karim MA, Aziz T, Sarmin Rapti S, Bindu RA, Hossain MS (2021) Covid-19 Pandemic in Bangladesh: Policy Responses and its Impact. https://www.bb.org.bd/pub/special//covid19_06072 021.pdf

Zeithaml VA (1988) Consumer perceptions of price, quality, and value: a means-end model and synthesis of evidence. J Mark 52(3):222. https://doi.org/10.1177/002224298805200302

Zhao Y, Bacao F (2021) How does the pandemic facilitate mobile payment? An investigation on users' perspective under the COVID19 pandemic. Int J Environ Res Public Health 18(3):1-22. https:// doi.org/10.3390/ijerph18031016

Zheng GW, Siddik AB, Masukujjaman M, Fatema N, Alam SS (2021) Green finance development in Bangladesh: the role of private commercial banks (PCBs). Sustainability (Switzerland) 13(2):117. https://doi.org/10.3390/su13020795

Publisher's note Springer Nature remains neutral with regard to jurisdictional claims in published maps and institutional affiliations. 